\title{
Resveratrol and cancer: focus on in vivo evidence
}

\author{
Lindsay G Carter, John A D'Orazio' and Kevin J Pearson \\ Graduate Center for Nutritional Sciences, Markey Cancer Center, University of Kentucky College of Medicine, \\ Wethington Building, Room 591, 900 South Limestone, Lexington, Kentucky 40536-0200, USA \\ ${ }^{1}$ Department of Pediatrics, Graduate Center for Toxicology, Markey Cancer Center, University of Kentucky College \\ of Medicine, Lexington, Kentucky 40536-0096, USA
}

Correspondence should be addressed to K J Pearson Email kevin.pearson@uky.edu

\begin{abstract}
Resveratrol is a naturally occurring polyphenol that provides a number of anti-aging health benefits including improved metabolism, cardioprotection, and cancer prevention. Much of the work on resveratrol and cancer comes from in vitro studies looking at resveratrol actions on cancer cells and pathways. There are, however, comparatively fewer studies that have investigated resveratrol treatment and cancer outcomes in vivo, perhaps limited by its poor bioavailability when taken orally. Although research in cell culture has shown promising and positive effects of resveratrol, evidence from rodents and humans is inconsistent. This review highlights the in vivo effects of resveratrol treatment on breast, colorectal, liver, pancreatic, and prostate cancers. Resveratrol supplementation in animal models of cancer has shown positive, neutral as well as negative outcomes depending on resveratrol route of administration, dose, tumor model, species, and other factors. Within a specific cancer type, there is variability between studies with respect to strain, age, and sex of animal used, timing and method of resveratrol supplementation, and dose of resveratrol used to study cancer endpoints. Together, the data suggest that many factors need to be considered before resveratrol can be used for human cancer prevention or therapy.
\end{abstract}

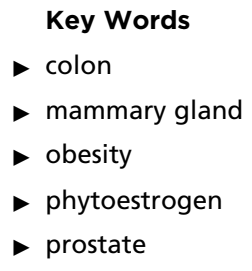

Endocrine-Related Cancer (2014) 21, R209-R225

\section{Introduction}

Resveratrol (trans-3,5,4'-trihydroxystilbene) is a phytoalexin found in many plant species, including those often consumed by humans such as grapes, peanuts, and berries; it is produced in plants in response to mechanical injury, fungal infection, and u.v. radiation (Langcake \& Pryce 1976). The highest naturally occurring levels of resveratrol are found in Polygonum cuspidatum (Japanese knotweed), a plant which has been used for hundreds of years in traditional Asian medicine to treat inflammation and other ailments (Vastano et al. 2000, Burns et al. 2002). Concentrations of resveratrol vary markedly between plant species. In blueberries, for example, resveratrol concentrations approximate only $32 \mathrm{ng} / \mathrm{g}$, compared with levels up to 1920 and $3540 \mathrm{ng} / \mathrm{g}$ in peanuts and grapes respectively (other beneficial compounds are also present in varying quantities; Sanders et al. 2000, Burns et al. 2002, Lyons et al. 2003). Resveratrol is not only found in these plants, but also in processed products such as wine. In fact, many attribute the 'French Paradox' in which moderate wine consumption is associated with decreased risk of coronary heart disease (Renaud \& de Lorgeril 1992), to be the result of red wine's relatively high resveratrol concentration (0.1-14.3 mg/l) (Goldberg et al. 1995, Kiraly-Veghely et al. 1998, Kopp 1998, Pervaiz 2003). Nonetheless, wine's resveratrol content is typically much lower than what has been shown experimentally to have 
health benefits, but recent work has suggested that lower levels of resveratrol can also provide health improvements (Tome-Carneiro et al. 2012). For a review and discussion of the clinical literature along with the limitations of preclinical and in vitro resveratrol studies, see TomeCarneiro et al. (2013). Further, Baur \& Sinclair (2006) provide a thorough review of the in vivo effects of resveratrol on many disease states.

Because resveratrol is a naturally occurring compound, it has been highly studied for the prevention and treatment of many diseases including cancer. After Jang et al. (1997) found that topical application of resveratrol protected mice from tumorigenesis in a skin cancer model in 1997, a wealth of publications followed. In animals, supplemental doses of resveratrol protect against many of the deleterious effects of high-fat diets and provide additional health benefits (Hung et al. 2000, Bradamante et al. 2004, Baur et al. 2006, Lagouge et al. 2006, Pearson et al. 2008, Ramadori et al. 2009, Kang et al. 2010). Numerous in vitro studies have shown that resveratrol has multiple anti-cancer effects, protecting against both tumor initiation and cancer progression pathways. For example, resveratrol can promote cell cycle arrest leading to apoptosis of tumor cells, prevent tumor-derived nitric oxide synthase expression to block tumor growth and migration, as well as act as an antioxidant to prevent DNA damage that can lead to tumor formation (Clement et al. 1998, Tsai et al. 1999, Nakagawa et al. 2001, Murakami et al. 2003, Garvin et al. 2006, Kalra et al. 2008). In addition, resveratrol inhibits cyclooxygenase (COX) activity, which is known to play a role in tumorigenesis by converting arachidonic acid to prostaglandins, inflammatory compounds that promote tumor cell proliferation (Subbaramaiah et al. 1998, Jang \& Pezzuto 1999, MacCarrone et al. 1999). Resveratrol has also been shown in multiple studies to decrease DNA binding activity of nuclear factor $\kappa \mathrm{B}(\mathrm{NF}-\kappa \mathrm{B})$, which is a transcription factor that is known to be upregulated in cancers and can drive the transcription of genes that promote tumor growth (Holmes-McNary \& Baldwin 2000, Benitez et al. 2009, Csaki et al. 2009, Roy et al. 2009).

Resveratrol appears to have many anti-tumor effects on different cancer cells in vitro and these effects and pathways have been extensively reviewed (Bhat \& Pezzuto 2002, Dong 2003, Le Corre et al. 2005, Kundu \& Surh 2008, Shukla \& Singh 2011). Regarding in vivo evidence, Jang et al. (1997) were the first to show that resveratrol may act as a chemopreventative agent when they found that topical application of the compound was able to inhibit tumor formation in the two-stage skin cancer model in mice. Later studies found that in mouse models of skin tumorigenesis, topical resveratrol prevented tumor formation by promoting apoptosis, regulating the cell cycle, and inhibiting COX activity and prostaglandin production (Afaq et al. 2003, Reagan-Shaw et al. 2004, Kalra et al. 2008). The in vivo use and efficacy of resveratrol for other types of cancer that require oral consumption or injection of resveratrol, however, have been less straight forward. This is due, in part, to the poor bioavailability of transresveratrol. Wenzel \& Somoza (2005) provide a critical and detailed review of the bioavailability and metabolism of resveratrol. In rodents and humans, when resveratrol is consumed orally, $70-80 \%$ is quickly absorbed via passive diffusion in the intestines (Andlauer et al. 2000, Soleas et al. 2001, Kaldas et al. 2003, Walle et al. 2004). After absorption, resveratrol is conjugated into glucuronides and sulfates, so that circulating levels of trans-resveratrol peak 30-60 min post oral administration (Andlauer et al. 2000, De Santi et al. 2000, Soleas et al. 2001, Yu et al. 2002). In humans, circulating levels of unmodified transresveratrol are only $\sim 2 \%$ of the peak serum concentration of total free resveratrol and conjugates after a single dose of $25 \mathrm{mg} / 70 \mathrm{~kg}$ body weight (BW; Goldberg et al. 2003). Another report shows that at least $70 \%$ of resveratrol is absorbed after a single $25 \mathrm{mg}$ dose, and there is a peak serum concentration of $2 \mu \mathrm{M}(\sim 490 \mathrm{ng} / \mathrm{ml})$ for resveratrol and all of its metabolites (Walle et al. 2004). After multiple oral doses ( $5 \mathrm{~g}$ daily for 29 days), plasma concentrations of trans-resveratrol have been reported to be as high as $\sim 4 \mu \mathrm{M}(4.29 \mathrm{nmol} / \mathrm{ml})$; however, it should be noted that resveratrol at this high dose was also associated with gastrointestinal side effects (Brown et al. 2010). Interestingly, in human colon tissue, levels of resveratrol and its metabolite resveratrol-3-O-glucuronide have been found at high concentrations ( 674 and $86 \mathrm{nmol} / \mathrm{g}$ respectively) when $0.5-1.0 \mathrm{~g}$ of resveratrol was taken orally once per day (Patel et al. 2010). In this study, resveratrol supplementation was shown to decrease cellular proliferation by $5 \%$ in colorectal cancer tissue, as assessed by Ki67 staining (Patel et al. 2010). Since there is such rapid conjugation and low bioavailability of resveratrol, the in vivo use of resveratrol for cancer prevention and treatment is uncertain. Therefore, it is the intention of this review to highlight findings from in vivo studies.

First, this review will briefly discuss the limited clinical evidence currently available on resveratrol and cancer treatment and prevention. Then, given the vast amount of research done with resveratrol and cancer (a PubMed search of 'resveratrol and cancer' yielded more than 1800 hits) and the more recent interest in obesity as a risk factor

Published by Bioscientifica Ltd. 
for cancer, this review will focus primarily on the in vivo studies involving resveratrol and several obesity-related cancers; specifically breast, colorectal, hepatic, pancreatic, and prostate cancers. Tables 1, 2, 3, 4 and 5 summarize the methods and outcomes of in vivo experiments that have tumor formation as an endpoint measurement rather than those studies that investigate the mechanisms, biomarkers, or pathway changes.

\section{Clinical studies}

Clinical evidence for resveratrol as an effective supplement for cancer prevention and treatment is scarce. In 2009, the first phase I clinical trial looking at resveratrol treatment in patients diagnosed with cancer was published (Nguyen et al. 2009). Patients with colorectal cancer $(n=8)$ had normal and cancerous intestinal mucosal samples biopsied at the time of diagnosis and 14 days after daily resveratrol ( 20 or $80 \mathrm{mg} /$ day; $n=2$ and 1 respectively) or grape powder ( 80 or $120 \mathrm{~g} /$ day; $n=3$ and 2 respectively) oral supplementation at the time of colon cancer resection surgery. The Wnt signaling pathway, known to be involved in the formation of colon cancer, was evaluated in normal and cancerous mucosa, before and after resveratrol or grape powder supplementation. Target genes in the Wnt pathway were significantly higher in cancerous compared with normal mucosa. Resveratrol and grape powder administration had no effect on cancerous mucosa Wnt signaling, but their supplementation resulted in decreased Wnt target gene expression in normal mucosa (effects of all treatment groups combined). The most significant effects were observed with the low-dose

Table 1 Breast cancer

\begin{tabular}{|c|c|c|c|c|c|c|}
\hline References & Strain/species & Sex & $\mathbf{A g e}^{a}$ & Tumor model & $\begin{array}{l}\text { Resveratrol dose } \\
\text { and administration }\end{array}$ & $\begin{array}{l}\text { Effect on } \\
\text { tumorigenesis }\end{array}$ \\
\hline Bhat et al. (2001) & $\begin{array}{l}\text { Sprague-Dawley } \\
\text { rats }\end{array}$ & $\mathrm{F}$ & 42 days & NMU & $\begin{array}{l}\text { I.g.; } 10 \text { or } 100 \mathrm{mg} / \mathrm{kg} \mathrm{BW} \text { B } \\
5 \times / \text { week; } 7 \text { days before } \\
\text { initiation }-120 \text { days after }\end{array}$ & Positive $^{c}$ \\
\hline $\begin{array}{l}\text { Banerjee et al. } \\
\quad(2002)\end{array}$ & $\begin{array}{l}\text { Sprague-Dawley } \\
\text { rats }\end{array}$ & $\mathrm{F}$ & 45 days & DMBA & $\begin{array}{l}0.001 \% \text { in diet; } 100 \mu \mathrm{g} / \mathrm{rat} \\
\text { daily; } 7 \text { days before } \\
\text { initiation - } 120 \text { days after } \\
\text { initiation }\end{array}$ & Positive \\
\hline Bove et al. (2002) & BALB/c mice & $\mathrm{F}$ & 17 weeks & 4T1 cells & $\begin{array}{l}\text { I.p.; } 1,3 \text {, or } 5 \mathrm{mg} / \mathrm{kg} \text { BW; daily; } \\
23 \text { days started at injection }\end{array}$ & Unchanged \\
\hline Sato et al. (2003) & $\begin{array}{l}\text { Sprague-Dawley } \\
\text { rats }\end{array}$ & $\mathrm{F}$ & 15 days & NMU & $\begin{array}{l}\text { S.C.; } 10 \text { or } 100 \mathrm{mg} / \mathrm{kg} \text { BW; daily } \\
\text { for } 5 \text { days; from } 30 \text { to } 34 \text { days } \\
\text { before initiation }\end{array}$ & Negative $^{c}$ \\
\hline $\begin{array}{l}\text { Provinciali et al. } \\
\quad \text { (2005) }\end{array}$ & HER2/neu mice & $\mathrm{F}$ & 20 weeks & $\begin{array}{l}\text { Spontaneous } \\
\text { tumors }\end{array}$ & $\begin{array}{l}0.0001 \% \text { in drinking water; } \\
4 \mu \mathrm{g} / \mathrm{mouse} \text { daily; for } \\
11 \text { weeks }\end{array}$ & Positive \\
\hline Garvin et al. (2006) & Nude mice & $F$ & $6-8$ weeks & $\begin{array}{l}\text { MDA-MB-231 } \\
(\operatorname{ER} \alpha(-), \operatorname{ER} \beta(+)) \\
\text { cells }\end{array}$ & $\begin{array}{l}\text { I.p.; } 25 \mathrm{mg} / \mathrm{kg} \mathrm{BW} \text {; daily; for } \\
3 \text { weeks after tumor size } \\
\text { reached } 40 \mathrm{~mm}^{3}\end{array}$ & Positive \\
\hline $\begin{array}{l}\text { Whitsett et al. } \\
\text { (2006) }\end{array}$ & $\begin{array}{l}\text { Sprague-Dawley } \\
\text { rats }\end{array}$ & $\mathrm{F}$ & 0 days & DMBA & $\begin{array}{l}0.1 \% \text { in diet; daily; } 50 \text { days } \\
\text { before initiation - } 18 \text { weeks } \\
\text { after initiation }\end{array}$ & Positive \\
\hline $\begin{array}{l}\text { Chatterjee et al. } \\
\text { (2011) }\end{array}$ & $\begin{array}{l}\text { Sprague-Dawley } \\
\text { rats }\end{array}$ & $\mathrm{F}$ & 5 weeks & DMBA & $\begin{array}{l}0.001 \% \text { in diet; } 100 \mu \mathrm{g} / \mathrm{rat} \\
\text { daily; } 2 \text { weeks before } \\
\text { initiation - } 24 \text { weeks after } \\
\text { initiation }\end{array}$ & Positive \\
\hline $\begin{array}{l}\text { Castillo-Pichardo } \\
\text { et al. (2013) }\end{array}$ & SCID mice & $\mathrm{F}$ & 5-6 weeks & $\begin{array}{l}\text { MDA-MB-231 } \\
(\operatorname{ER} \alpha(-), \operatorname{ER} \beta(+)) \\
\text { cells }\end{array}$ & $\begin{array}{l}\text { Gavage; } 0.5,5 \text {, or } 50 \mathrm{mg} / \mathrm{kg} \\
\text { BW; } 5 \times / \text { week; } 7 \text { days after } \\
\text { injection for } 108 \text { days }\end{array}$ & Negative \\
\hline $\begin{array}{l}\text { Castillo-Pichardo } \\
\text { et al. (2013) }\end{array}$ & Nude mice & $F$ & 5-6 weeks & $\begin{array}{l}\text { MDA-MB-435 } \\
(\mathrm{ER}(-)) \text { cells }\end{array}$ & $\begin{array}{l}\text { Gavage; } 0.5,5 \text {, or } 50 \mathrm{mg} / \mathrm{kg} \\
\text { BW; } 5 \times / \text { week; } 7 \text { days after } \\
\text { injection for } 44 \text { days }\end{array}$ & Negative \\
\hline
\end{tabular}

BW, body weight; DMBA, 7,12-dimethylbenz(a)anthracene; ER, estrogen receptor; F, female; i.g., intragastric intubation; NMU, $N$-nitroso- $N$-methylurea; SCID, severe combined immunodeficiency.

${ }^{a} \mathrm{Age}$ in table indicates age of animal when study was started; either when tumors were initiated or when resveratrol was administered, depending on study design.

${ }^{\mathrm{b}}$ Review authors' interpretation of paper results with a focus on tumor outcomes.

'Lower dose did not significantly affect outcomes.

http://erc.endocrinology-journals.org DOI: 10.1530/ERC-13-0171
(C) 2014 The authors Printed in Great Britain
Published by Bioscientifica Ltd. 
Table 2 Colorectal cancer

\begin{tabular}{|c|c|c|c|c|c|c|}
\hline References & Strain/species & Sex & Age $^{a}$ & Tumor model & $\begin{array}{l}\text { Resveratrol dose } \\
\text { and administration }\end{array}$ & $\begin{array}{l}\text { Effect on } \\
\text { tumorigenesis }^{\mathrm{b}}\end{array}$ \\
\hline $\begin{array}{l}\text { Tessitore et al. } \\
\text { (2000) }\end{array}$ & F344 rats & M & 8 weeks & AOM & $\begin{array}{l}\text { In drinking water; } 200 \mu \mathrm{g} / \mathrm{kg} \mathrm{BW} \\
\text { daily; } 10 \text { days before initiation, } \\
\text { continued for } 100 \text { days }\end{array}$ & Positive \\
\hline $\begin{array}{l}\text { Schneider et al. } \\
\text { (2001) }\end{array}$ & $\mathrm{APC}^{\mathrm{Min}} /+$ mice & M & 5 weeks & $\begin{array}{l}\text { Spontaneous } \\
\text { tumors }\end{array}$ & $\begin{array}{l}0.01 \% \text { in drinking water; between } \\
0.3 \text { and } 0.4 \mathrm{mg} / \mathrm{mouse} \text { daily for } \\
7 \text { weeks }\end{array}$ & Positive \\
\hline $\begin{array}{l}\text { Ziegler et al. } \\
\quad(2004)\end{array}$ & $\mathrm{APC}^{\mathrm{Min}} /+$ mice & $M$ & 43 days & $\begin{array}{l}\text { Spontaneous } \\
\text { tumors }\end{array}$ & $\begin{array}{l}\text { In diet; } 4,20 \text {, or } 90 \mathrm{mg} / \mathrm{kg} \text { BW daily } \\
\text { for } 7 \text { weeks }\end{array}$ & Unchanged \\
\hline $\begin{array}{l}\text { Sale et al. } \\
\text { (2005) }\end{array}$ & $\mathrm{APC}^{\mathrm{Min}} /+$ mice & $M$ & 4 weeks & $\begin{array}{l}\text { Spontaneous } \\
\text { tumors }\end{array}$ & $\begin{array}{l}0.05 \text { or } 0.2 \% \text { in diet; } 60 \text { or } 240 \mathrm{mg} / \mathrm{kg} \\
\text { BW daily for } 10-14 \text { weeks }\end{array}$ & Positive $^{c}$ \\
\hline $\begin{array}{l}\text { Sengottuvelan \& } \\
\quad \text { Nalini (2006) }\end{array}$ & Wistar rats & $M$ & Adult & $\mathrm{DMH}$ & $\begin{array}{l}\text { I.g.; } 8 \mathrm{mg} / \mathrm{kg} \mathrm{BW} \text {; daily; } 2 \text { weeks } \\
\text { before first DMH - final DMH }{ }^{\mathrm{d}}\end{array}$ & Positive \\
\hline $\begin{array}{l}\text { Sengottuvelan \& } \\
\quad \text { Nalini (2006) }\end{array}$ & Wistar rats & M & Adult & $\mathrm{DMH}$ & $\begin{array}{l}\text { I.g.; } 8 \mathrm{mg} / \mathrm{kg} \mathrm{BW} \text {; daily; } 2 \text { days after } \\
\text { final } \mathrm{DMH}-15 \text { weeks after final } \\
\mathrm{DMH}^{\mathrm{d}}\end{array}$ & Positive \\
\hline $\begin{array}{l}\text { Sengottuvelan \& } \\
\text { Nalini (2006) }\end{array}$ & Wistar rats & $M$ & Adult & $\mathrm{DMH}$ & $\begin{array}{l}\text { I.g.; } 8 \mathrm{mg} / \mathrm{kg} \mathrm{BW} \text {; daily; on day of } \\
\text { first } \mathrm{DMH}-30 \text { weeks after }\end{array}$ & Positive \\
\hline $\begin{array}{l}\text { Majumdar et al. } \\
\text { (2009) }\end{array}$ & SCID mice & $F$ & 7 weeks & HCT-116 (wt) cells & $\begin{array}{l}\text { Gavage; } 150 \mathrm{mg} / \mathrm{kg} \mathrm{BW} \text {; daily; } \\
15 \text { days after injection for } 3 \text { weeks }\end{array}$ & Positive \\
\hline $\begin{array}{l}\text { Alfaras et al. } \\
\quad(2010)\end{array}$ & $\begin{array}{l}\text { Sprague- } \\
\text { Dawley rats }\end{array}$ & $M$ & 8 weeks & $\mathrm{DMH}$ & $\begin{array}{l}\text { Gavage; } 60 \mathrm{mg} / \mathrm{kg} \text { BW; daily; } 7 \text { days } \\
\text { before initiation for } 49 \text { days }\end{array}$ & Positive \\
\hline
\end{tabular}

AOM, azoxymethane; BW, body weight; $\mathrm{DMH}, 1$,2-dimethylhydrazine; i.g., intragastric intubation; M, male; SCID, severe combined immunodeficiency. a Age in table indicates age of animal when study was started; either when tumors were initiated or when resveratrol was administered, depending on study design.

'Review authors' interpretation of paper results with a focus on tumor outcomes.

'Unchanged for lower dose.

dDMH was given once weekly for 15 weeks, and then the rats were killed 15 weeks after the last DMH injection (30 weeks after initial DMH exposure).

grape powder. This led the authors to conclude that resveratrol in combination with other compounds found in grapes could possibly be used to decrease the risk of colon cancer development by decreasing Wnt pathway signaling, but might not be as effective against established colon cancer. The second clinical study observed the effects of resveratrol treatment in colorectal cancer patients with hepatic metastasis $(n=9)$. Resveratrol supplementation (5 $\mathrm{g}$ daily of microionized resveratrol SRT501 for 10-21 days; $n=6$ ) increased the expression of cleaved caspase-3 in cancerous hepatic tissue, indicating increased apoptosis of cancerous cells compared with those of placebo-treated subjects $(n=3)$ (Howells et al. 2011). It is important to caution that patient sample size in these clinical trials was small (only eight and nine cancer patients were enrolled in the studies respectively), highlighting the fact that so far, there is very little human data for the efficacy of resveratrol in cancer treatment.

A few other clinical studies have focused on resveratrol supplementation and predictors for cancer prevention and cancer risk factors in healthy subjects. Given that increases in insulin-like growth factor 1 (IGF1) and decreases in IGFbinding protein 3 (IGFBP3) are associated with tumor formation and metastasis, one study looked at the effects of resveratrol supplementation $(0.5,1.0,2.5$, and $5 \mathrm{~g} /$ day for 29 days; $n=10-12 /$ dose) on circulating levels of these proteins (Brown et al. 2010). After 29 days of supplementation, the authors found that resveratrol treatment at $2.5 \mathrm{~g} /$ day significantly reduced IGF1 and IGFBP3 levels in plasma, which would support the use of resveratrol as a chemopreventative agent in humans. The $1.0 \mathrm{~g}$ /day dose also caused a significant decrease in plasma IGFBP3 compared with pretreatment baseline levels. The two higher doses did cause some short-term mild to moderate gastrointestinal symptoms in multiple subjects (Brown et al. 2010). In another trial, healthy subjects were given $1 \mathrm{~g}$ of resveratrol for 4 weeks and lymphocyte levels or surrogate markers of activity levels of enzymes involved in carcinogenesis and drug metabolism were measured (Chow et al. 2010). Resveratrol supplementation increased the protein or activity levels of a variety of carcinogendetoxifying enzymes, such as glutathione $S$-transferase and glucuronosyltransferase, but a significant increase was only reached where enzyme levels were low at baseline. Chow et al. (2010) noted the important caveat that although pharmacologic resveratrol supplementation seems well tolerated and may exert a cancer-protective effect through enhanced detoxification of carcinogens,

Published by Bioscientifica Ltd. 
Table 3 Liver cancer

\begin{tabular}{|c|c|c|c|c|c|c|}
\hline References & Strain/species & Sex & $\mathbf{A g e}^{\mathrm{a}}$ & Tumor model & $\begin{array}{l}\text { Resveratrol dose and } \\
\text { administration }\end{array}$ & $\begin{array}{l}\text { Effect on } \\
\text { tumorigenesis }^{\mathrm{b}}\end{array}$ \\
\hline $\begin{array}{l}\text { Carbo et al. } \\
\text { (1999) }\end{array}$ & Wistar rats & $\mathrm{M}$ & Adult ${ }^{c}$ & AH-130 cells & $\begin{array}{l}\text { I.p.; } 1 \mathrm{mg} / \mathrm{kg} \text { BW; daily; } 7 \text { days } \\
\text { starting at injection }\end{array}$ & Positive \\
\hline $\begin{array}{l}\text { Bishayee \& Dhir } \\
\quad(2009)\end{array}$ & $\begin{array}{l}\text { Sprague- } \\
\text { Dawley rats }\end{array}$ & $\mathrm{F}$ & $31-37$ days $^{d}$ & $\mathrm{DENA}+\mathrm{PB}$ & $\begin{array}{l}0.06,0.12, \text { or } 0.36 \% \text { in diet; } 50,100 \\
\text { or } 300 \mathrm{mg} / \mathrm{kg} \mathrm{BW} \text { daily; } 4 \text { weeks } \\
\text { before initiation - } 16 \text { weeks after }\end{array}$ & Positive $^{\mathrm{e}}$ \\
\hline $\begin{array}{l}\text { Luther et al. } \\
\qquad(2011)\end{array}$ & $\begin{array}{l}\text { Sprague- } \\
\text { Dawley rats }\end{array}$ & $\mathrm{F}$ & 31-37 days & $\mathrm{DENA}+\mathrm{PB}$ & $\begin{array}{l}0.06,0.12 \text {, or } 0.36 \% \text { in diet; } 50,100 \\
\text { or } 300 \mathrm{mg} / \mathrm{kg} \mathrm{BW} \text { daily; } 4 \text { weeks } \\
\text { before initiation - } 14 \text { weeks after }\end{array}$ & Positive \\
\hline $\begin{array}{l}\text { Rajasekaran et al. } \\
\text { (2011) }\end{array}$ & Wistar rats & $\mathrm{M}$ & 6-8 weeks & $\mathrm{DENA}+\mathrm{PB}$ & $\begin{array}{l}\text { Gavage; } 20 \mathrm{mg} / \mathrm{kg} \mathrm{BW} \text {; daily; on day } \\
\text { of initiation - } 15 \text { days after }\end{array}$ & Positive \\
\hline $\begin{array}{l}\text { Rajasekaran et al. } \\
\text { (2011) }\end{array}$ & Wistar rats & $\mathrm{M}$ & 6-8 weeks & $\mathrm{DENA}+\mathrm{PB}$ & $\begin{array}{l}\text { Gavage; } 20 \mathrm{mg} / \mathrm{kg} \text { BW; daily; for } \\
15 \text { days from } 17 \text { to } 18 \text { weeks after } \\
\text { initiation }\end{array}$ & Positive \\
\hline $\begin{array}{l}\text { Salado et al. } \\
\quad(2011)\end{array}$ & C57BL/6J mice & $\mathrm{M}$ & 6-8 weeks & $\begin{array}{l}\text { B16M cells } \\
\text { metastasis }\end{array}$ & $\begin{array}{l}\text { I.g.; } 1 \mathrm{mg} / \mathrm{kg} \mathrm{BW} \text {; daily; day of } \\
\text { injection - } 12 \text { days after }\end{array}$ & Positive \\
\hline Lin et al. (2012) & HBx mice & $\mathrm{M}$ & 12 months & $\begin{array}{l}\text { Spontaneous } \\
\text { tumors }\end{array}$ & $\begin{array}{l}0.024 \% \text { in diet; } 30 \mathrm{mg} / \mathrm{kg} \mathrm{BW} \text { daily; } \\
\text { for } 4 \text { months }\end{array}$ & Positive \\
\hline
\end{tabular}

BW, body weight; DENA, diethylnitrosamine; F, female; HBx, hepatitis B virus X protein; i.g., intragastric intubation; M, male; PB, phenobarbital. ${ }^{a} A g e$ in table indicates age of animal when study was started; either when tumors were initiated or when resveratrol was administered, depending on study design.

${ }^{b}$ Review authors' interpretation of paper results with a focus on tumor outcomes.

${ }^{\mathrm{C}}$ Age was not given but the rats were $\sim 100 \mathrm{~g}$.

${ }^{\mathrm{d}}$ Age was not given but the rats were the same weight $(65-85 \mathrm{~g})$ as the group's next paper (Luther et al. 2011).

eUnchanged for lowest dose.

it might also have the potential to alter the metabolism of a variety of medications through the inhibition of cytochrome P450 activity. Therefore resveratrol's safety and benefit must be further delineated, particularly in the context of co-administering it with pharmaceutical agents.

From this limited clinical trial data, it is apparent that much more human research is needed before resveratrol can be considered as a viable option for cancer prevention or therapy. There are several other completed clinical trials looking at resveratrol and cancer that have yet to publish results and one on-going clinical trial (clinicaltrials.gov). All of these trials are focusing either on patients with colorectal cancer or are assessing cancer prevention capabilities of resveratrol in healthy patients. Thus far, its most promising use seems to be in cancer prevention instead of treatment. It is important to note that there is some evidence that resveratrol may have adverse effects in certain cancer patients. In a phase II clinical trial involving relapsed or refractory multiple myeloma patients, resveratrol at a dose of $5 \mathrm{~g}$ /day caused adverse events (including nausea, diarrhea, fatigue, and renal toxicity), which may have contributed to the death of one patient and caused the investigators to prematurely end the study (Popat et al. 2013). The authors note that this high dose has been shown to be safe in other clinical trials in healthy patients. This highlights the need for more research into the efficacy and safety of resveratrol in in vivo cancer models. Later we will discuss much of the work that has been completed with resveratrol use in animal models of breast, colorectal, hepatic, pancreatic, and prostate cancers.

\section{Animal studies}

\section{Breast cancer}

Breast cancer accounts for one in three diagnosed cancers in women in the USA (DeSantis et al. 2011a,b). Current treatment options for breast cancer include chemotherapy, radiation, or surgery to remove tumors and breast tissue. Hormone therapy is also available, especially for post-menopausal women. Resveratrol is considered a phytoestrogen that seems to have both agonistic and antagonistic effects on estrogen (Bowers et al. 2000, Bhat et al. 2001). Given this, it makes sense that research conducted on resveratrol and estrogen-related cancers have found diverse results. In several animal models, resveratrol supplementation was shown to decrease the incidence of mammary tumor formation. In 45-day old female Sprague-Dawley rats, resveratrol supplementation in the diet $(0.001 \%$; daily intake calculated to be $100 \mu \mathrm{g} / \mathrm{rat}$ ) started 7 days before tumor initiation and continued for 120 days after initiation was found to

Published by Bioscientifica Ltd 
Table 4 Pancreatic cancer

\begin{tabular}{|c|c|c|c|c|c|c|}
\hline References & Strain/species & Sex & Age $^{a}$ & Tumor model & $\begin{array}{l}\text { Resveratrol dose and } \\
\text { administration }\end{array}$ & $\begin{array}{l}\text { Effect on } \\
\text { tumorigenesis }^{\mathrm{b}}\end{array}$ \\
\hline $\begin{array}{l}\text { Kuroiwa et al. } \\
\text { (2006) }\end{array}$ & Syrian hamsters & M & 6 weeks & BOP & $\begin{array}{l}0.001 \% \text { in diet; daily; } 1 \text { week before } \\
\text { initiation for } 3 \text { weeks }\end{array}$ & Unchanged \\
\hline $\begin{array}{l}\text { Kuroiwa et al. } \\
\text { (2006) }\end{array}$ & Syrian hamsters & M & 6 weeks & BOP & $\begin{array}{l}0.001 \% \text { in diet; daily; } 1 \text { week after initial } \\
\text { BOP injection for } 14 \text { weeks }\end{array}$ & Unchanged \\
\hline $\begin{array}{l}\text { Harikumar et al. } \\
\text { (2010) }\end{array}$ & Nude mice & M & 4 weeks & $\begin{array}{l}\text { MIA PaCa-2 } \\
\text { cells }\end{array}$ & $\begin{array}{l}\text { Gavage; } 40 \mathrm{mg} / \mathrm{kg} \mathrm{BW} \text {; daily; } 1 \text { week } \\
\text { after injection for } 4 \text { weeks }\end{array}$ & Positive \\
\hline Oi et al. (2010) & Nude mice & - & $6-8$ weeks & $\begin{array}{l}\text { MIA PaCa-2 } \\
\text { cells }\end{array}$ & $\begin{array}{l}\text { Gavage; } 10 \text { or } 50 \mathrm{mg} / \mathrm{kg} \mathrm{BW} \\
5 \times / \text { week; } 2 \text { weeks before injection - } \\
\text { tumors reaching } 1 \mathrm{~cm}^{3} \text { volume }\end{array}$ & Positive $^{c}$ \\
\hline Roy et al. (2011) & Nude mice & - & 4-6 weeks & PANC-1 cells & $\begin{array}{l}\text { Gavage; } 20,40 \text {, or } 60 \mathrm{mg} / \mathrm{kg} \mathrm{BW} \text {; } \\
5 \times / \text { week, } 1 \text { week after injection } \\
\text { for } 6 \text { weeks }\end{array}$ & Positive \\
\hline $\begin{array}{l}\text { Shankar et al. } \\
\text { (2011) }\end{array}$ & $\mathrm{Kras}^{\mathrm{G} 12} \mathrm{D}$ mice & - & 8 weeks & $\begin{array}{l}\text { Spontaneous } \\
\text { tumors }\end{array}$ & $\begin{array}{l}\text { Gavage; } 40 \mathrm{mg} / \mathrm{kg} \mathrm{BW} \text { B } 5 \times / \text { week; } \\
\text { for } \sim 10 \text { months }\end{array}$ & Positive \\
\hline
\end{tabular}

BOP, $N$-nitrosobis(2-oxopropyl)amine); BW, body weight; $\mathrm{M}$, male.

${ }^{a}$ Age in table indicates age of animal when study was started; either when tumors were initiated or when resveratrol was administered, depending on study design.

${ }^{b}$ Review authors' interpretation of paper results with a focus on tumor outcomes.

'The protection was dose dependent, but the lower dose was not significantly improved compared to vehicle control.

increase time to first tumor formation and decrease tumor incidence and multiplicity following 7,12-dimethylben$\mathrm{z}(a)$ anthracene (DMBA) administration (Banerjee et al. 2002). Analysis of the tumor tissue also showed that resveratrol reduced DMBA-generated COX2 expression and NF- $\mathrm{KB}$ binding to DNA. In a similar rat mammary tumor model, supplementation of a higher dose of resveratrol in the diet $(0.1 \%)$, starting at birth and continuing for 180 days, decreased tumor number per rat and increased latency to tumor development after tumor initiation at postnatal day 50 (Whitsett et al. 2006). For resveratrol supplementation starting at birth, nursing dams were fed the diets containing resveratrol and pups were then weaned onto the same diet. Cellular proliferation and apoptosis in the mammary tumor tissue was also measured. Proliferating cell percentage was reduced with resveratrol treatment, while apoptotic-labeling index (epithelial cells stained positive for apoptosis/total number of epithelial cells) was increased compared with control diet-fed rats (Whitsett et al. 2006).

Using young, 5-week-old female Sprague-Dawley rats and a DMBA carcinogenesis model, Chatterjee et al. (2011) found that resveratrol supplementation in the diet (0.001\%; daily intake calculated to be $100 \mu \mathrm{g} / \mathrm{rat})$ decreased palpable mammary tumor incidence 11 weeks after DMBA exposure. After 24 weeks of supplementation, animals were killed and mammary tissue was analyzed for DNA damage, 5-lipoxygenase (5-LOX), transforming growth factor $\beta 1$ (TGF $\beta 1$ ), NF- $\kappa \mathrm{B}$, cell proliferation, and apoptosis, all of which can be the indicators of tumorigenesis. Resveratrol treatment positively impacted all of these markers in the mammary tissue; it decreased the appearance of single-strand DNA, indicating less DNA damage; decreased 5-LOX expression and activity; decreased TGF $\beta 1$ and NF- $\mathrm{BB}$ expression; decreased cell proliferation; and increased the number of apoptotic cells. In a different model of rat mammary tumorigenesis using $\mathrm{N}$-nitroso- $\mathrm{N}$-methylurea (NMU) to promote tumor formation in 49-day-old Sprague-Dawley females, resveratrol was given by oral gavage ( 10 or $100 \mathrm{mg} / \mathrm{kg} \mathrm{BW}$ ) five times a week for 1 week before NMU injection and continued for 120 days after. The higher dose of resveratrol resulted in a significant delay in tumor formation and decrease in tumor multiplicity, while the lower dose did not significantly alter these parameters compared with control (Bhat et al. 2001). In a model of spontaneous mammary tumor formation, 20-week-old female FVB/N HER2/neu transgenic mice treated with resveratrol in their drinking water ( $0.0001 \%$; daily intake calculated to be $4 \mu \mathrm{g} /$ mouse) for 11 weeks had a significant increase in latency to tumor formation. Resveratrol treatment also decreased tumor number and size per animal and reduced tumor metastasis to the lungs (Provinciali et al. 2005). In a xenograft model where athymic nude female mice from 6 to 8 weeks of age were injected with MDA-MB-231 (estrogen receptor (ER) $\alpha(-)$, $\operatorname{ER} \beta(+))$ cells, Garvin et al. found that resveratrol $(25 \mathrm{mg} / \mathrm{kg}$ BW; i.p. injection) given daily for 3 weeks after tumors had already reached $40 \mathrm{~mm}^{3}$ caused a significant reduction in tumor growth. Tumors in vehicle-treated controls increased in size by four- to

Published by Bioscientifica Ltd. 
Table 5 Prostate cancer

\begin{tabular}{|c|c|c|c|c|c|c|}
\hline References & Strain/species & Sex & $\mathbf{A g e}^{a}$ & Tumor model & $\begin{array}{l}\text { Resveratrol dose } \\
\text { and administration }\end{array}$ & $\begin{array}{l}\text { Effect on } \\
\text { tumorigenesis }^{\mathrm{b}}\end{array}$ \\
\hline $\begin{array}{l}\text { Harper et al. } \\
(2007)\end{array}$ & TRAMP mice & $\mathrm{M}$ & 5 weeks & $\begin{array}{l}\text { Spontaneous } \\
\text { tumors }\end{array}$ & $0.0625 \%$ in diet; daily for 23 weeks & Positive \\
\hline Seeni et al. (2008) & TRAP rats & $\mathrm{M}$ & 3 weeks & $\begin{array}{l}\text { Spontaneous } \\
\text { tumors }\end{array}$ & $\begin{array}{l}0.005,0.01 \text {, or } 0.02 \% \text { in drinking water; } \\
\text { daily for } 7 \text { weeks }\end{array}$ & Positive \\
\hline Seeni et al. (2008) & Nude mice & $\mathrm{M}$ & 6 weeks & PLS30 cells & $\begin{array}{l}0.01 \text { or } 0.02 \% \text { daily in drinking water; } \\
1 \text { week after cell } \\
\text { injection }-6 \text { weeks after }\end{array}$ & Unchanged \\
\hline $\begin{array}{l}\text { Wang et al. } \\
\text { (2008) }\end{array}$ & Nude mice & $\mathrm{M}$ & 5 weeks & LNCaP cells & $\begin{array}{l}0.005 \text { or } 0.01 \% \text { in diet; daily; } 2 \text { weeks } \\
\text { before cell injection - } 7 \text { weeks after }\end{array}$ & Unchanged $^{\mathrm{c}}$ \\
\hline Dias et al. (2013) & Nude mice & $\mathrm{M}$ & 6-7 weeks & LNCaP cells & $\begin{array}{l}\text { Gavage; } 50 \mathrm{mg} / \mathrm{kg} \mathrm{BW} \text {; every other day; } \\
2 \text { weeks prior to cell injection - } \\
5 \text { weeks after }\end{array}$ & Positive \\
\hline
\end{tabular}

BW, body weight; M, male; TRAP, transgenic rats for adenocarcinoma of prostate; TRAMP, transgenic adenocarcinoma of mouse prostate.

${ }^{a}$ Age in table indicates age of animal when study was started; either when tumors were initiated or when resveratrol was administered, depending on study design.

${ }^{b}$ Review authors' interpretation of paper results with a focus on tumor outcomes.

'Resveratrol delayed tumor growth at 3 weeks (both doses) and 4 weeks (higher dose only) post injection compared with mice on control diet, but there were no differences in tumor size after 7 weeks at the end of the study.

fivefold over the next 3 weeks, while tumors in resveratroltreated mice did not increase in size. Furthermore, apoptosis was increased and angiogenesis was decreased in the tumor cells from resveratrol-compared with vehicle-treated mice (Garvin et al. 2006). Taken together, these animal models suggest that resveratrol could potentially be used as a chemopreventative or cancer treatment agent.

Other studies have not shown such promising results for resveratrol as a breast cancer therapy. In 17-week-old $\mathrm{BALB} / \mathrm{c}$ female mice, 4T1 mammary carcinoma cells (an $\mathrm{ER} \alpha$ - and $\operatorname{Er} \beta$-positive cell line) were injected and breast tumor formation and metastasis to the lungs were monitored (Bove et al. 2002). Mice that were treated with resveratrol at 1,3 , or $5 \mathrm{mg} / \mathrm{kg}$ BW daily (i.p. injection) for 23 days following tumor cell injection showed no differences in mammary tumor latency, mammary tumor number, or tumor metastasis to the lungs compared with vehicle-treated mice injected with the 4T1 cells (Bove et al. 2002). Castillo-Pichardo et al. injected low metastatic cells $\operatorname{ER} \alpha(-), \operatorname{ER} \beta(+)$ MDA-MB-231, or high metastatic $\mathrm{ER}(-) \mathrm{MDA}-\mathrm{MB}-435$ cancer cells into 5- to 6-week-old female mice with severe combined immunodeficiency (SCID) and athymic nude (nu/nu) respectively. They then evaluated tumor formation and metastasis with or without resveratrol supplementation $(0.5,5$, or $50 \mathrm{mg} / \mathrm{kg} \mathrm{BW}$; oral gavage) starting 7 days after tumor cell injection and continuing for 44 or 108 days (CastilloPichardo et al. 2013). At all concentrations of dietary supplementation and in both cell types, there was an increase in mammary tumor formation and metastasis compared with vehicle-treated mice. Because phytoestrogens such as resveratrol can affect development in prepubertal animals, Sato et al. (2003) treated female Sprague-Dawley rats daily with resveratrol on postnatal days $15-19$ (10 or $100 \mathrm{mg} / \mathrm{kg}$ BW; s.c. injection). On postnatal day 49 , rats were injected with NMU to promote mammary tumor formation. Resveratrol at $100 \mathrm{mg} / \mathrm{kg} \mathrm{BW}$ given on postnatal days 15-19 had no effect on tumor latency but increased the multiplicity of tumors and the incidence of rats with tumors $\geq 1 \mathrm{~cm}$. The lower dose did not cause the same negative effects, but it was not beneficial either (Sato et al. 2003). These studies suggest that caution must be applied in adapting resveratrol for human use and may indicate that resveratrol can promote mammary tumor growth and formation depending on cell type and other factors. A summary of these studies is provided in Table 1.

\section{Colorectal cancer}

Colorectal cancer is one of the leading causes of cancer deaths in the Western world (Siegel et al. 2012). Diet and lifestyle have been shown to have a significant impact on the development of colorectal cancers (Doll \& Peto 1981, Willett 1995), making resveratrol an interesting treatment possibility for this cancer type. Furthermore, oral administration of resveratrol might be expected to have a maximal impact on local intestinal processes before metabolic inactivation by the liver. Several different animal models have been used to evaluate the effect of resveratrol treatment on colon tumor formation. Using

Published by Bioscientifica Ltd. 
azoxymethane to induce colon tumorigenesis in 8-weekold male Fisher 344 rats, Tessitore et al. (2000) found that resveratrol supplementation in drinking water (daily intake calculated to be $200 \mu \mathrm{g} / \mathrm{kg}$ BW) for 100 days decreased the appearance of aberrant crypt foci (ACF) precursors for colon cancer compared with rats receiving control water. They also found that resveratrol treatment reduced the appearance of large-sized ACF as well as increased the expression of $B c l 2$-associated $\mathrm{X}$ (Bax), a proapoptotic protein in precancerous cells. Other studies have used 1,2-dimethylhydrazine (DMH) to promote colon tumor formation in rats in order to study the chemopreventative effects of resveratrol. Sengottuvelan \& Nalini exposed adult male Wistar rats to DMH once weekly for 15 weeks and then killed the rats 30 weeks after the initial $\mathrm{DMH}$ injection. The rats were then treated daily with vehicle or resveratrol ( $8 \mathrm{mg} / \mathrm{kg} \mathrm{BW}$; oral gavage): i) before and during DMH initiation (2 weeks before and throughout the 15 weeks DMH treatment), ii) after the final DMH treatment ( 2 days after the last DMH injection to the end of the study), and iii) from the initial DMH treatment until the end of the experiment. They found that all three resveratrol exposure protocols decreased tumor incidence and the number of ACF compared with vehicle-treated DMH rats (Sengottuvelan \& Nalini 2006). This same group also looked at the markers of inflammation, cell proliferation, and apoptosis in intestinal mucosa sampled from rats injected with DMH, with or without a similar resveratrol supplementation protocol. Resveratrol reduced COX2 expression and activity, decreased ornithine decarboxylase which is highly expressed in cells during cell proliferation and tumor promotion, and increased the presence of cleaved capsase-3, indicating cellular apoptosis (Sengottuvelan et al. 2009). In 8-week-old Sprague-Dawley male rats, treatment with resveratrol by gavage over a 49-day period starting 7 days before tumor initiation $(60 \mathrm{mg} / \mathrm{kg} \mathrm{BW})$ reduced the number of intestinal $\mathrm{ACF}$ as well as mucin-depleted foci (MDF) following DMH injection (Alfaras et al. 2010). MDF reduction is important because MDF foci are characterized by deregulated Wnt signaling (Yang et al. 2008), which is considered to be a major risk factor for colon cancer development (Moon et al. 2004, Sancho et al. 2004).

Other studies used a mouse model of spontaneous colon tumor formation. Adenomatous polyposis coli $(\mathrm{Apc})^{\mathrm{Min} /+}$ mice contain a germ line mutation in the tumor suppressor gene adenomatous polyposis and are predisposed to develop colon cancer (Wechter et al. 2000). Since spontaneous tumors in these mice are sensitive to COX inhibitors, resveratrol use to prevent tumor formation was of interest in this model (Jacoby et al. 1996, 2000). In one study, when 5-week-old male C57BL/6J-Apc ${ }^{\mathrm{Min} /+}$ mice were treated with resveratrol for 7 weeks $(0.01 \%$ in drinking water; daily intake calculated to be between 0.3 and $0.4 \mathrm{mg} /$ mouse per day), resveratrol supplementation resulted in a $70 \%$ reduction in small intestinal tumors compared with vehicle-treated control animals. Markers for cell cycle progression and proliferation were evaluated in the intestinal mucosa and resveratrol decreased cyclins D1 and D2 (Schneider et al. 2001). Using 4-week-old C57BL/6J-Apc ${ }^{\mathrm{Min} /+}$ mice, Sale et al. showed that resveratrol supplementation for 10-14 weeks in the diet $(0.2 \%$ of diet; $\sim 240 \mathrm{mg} / \mathrm{kg}$ BW daily) reduced adenoma number in the colon and small intestine compared with control $\mathrm{Apc}^{\mathrm{Min} /+}$ mice, but a lower dose did not significantly affect adenoma number $(0.05 \%$ of diet; $\sim 60 \mathrm{mg} / \mathrm{kg} \mathrm{BW}$ daily) (Sale et al. 2005). After 3 weeks on either the 0.05 or $0.2 \%$ resveratrol diet, levels of prostaglandin E2 (PGE2) in WT male C57BL/6J mice were reduced in the intestinal mucosa, suggesting decreased COX2 activity (Sale et al. 2005). Using C57BL/6J-Apc $\mathrm{Min} /+$ mice, however, Ziegler et al. (2004) were unable to show that resveratrol supplementation prevented tumor formation. Specifically, the incidence of tumors or Cox2 expression was no different between male mice given resveratrol (in diet; daily intake of 4,20 , or $90 \mathrm{mg} / \mathrm{kg}$ starting at $\sim 6$ weeks of age for 7 weeks) vs control. Sale et al. only detected differences in adenoma load at a dose that was much higher than either Ziegler et al. (no effect) or Schneider et al. (positive effect). Age at which this mouse model is treated may be critical in preventing tumor formation; Sale et al. and Schneider et al. started resveratrol treatment at 4 and 5 weeks of age, respectively, while Ziegler et al. waited until 6 weeks of age to start the supplementation. Ziegler et al., however, did find a significant decrease in PGE2 levels in the tumors treated with resveratrol at $90 \mathrm{mg} / \mathrm{kg} \mathrm{BW}$, suggesting that resveratrol was having some effect on Cox 2 activity in the intestinal mucosa (Ziegler et al. 2004).

Finally, resveratrol in combination with other natural compounds may also be a viable option for the treatment of colon cancers. In a recent study, 7-week-old female ICR SCID mice were injected with HCT-116 (wt) cells to initiate colon cancer formation, and 15 days post cell injection after tumors had formed, they were treated daily by oral gavage with both $500 \mathrm{mg} / \mathrm{kg}$ of curcumin and $150 \mathrm{mg} / \mathrm{kg}$ of resveratrol for 3 weeks (Majumdar et al. 2009). The combination of curcumin and resveratrol were able to significantly inhibit colon cancer cell growth compared with tumor growth in vehicle control mice, and

Published by Bioscientifica Ltd. 
this was associated with increases in apoptotic cells in the treated mice. Both resveratrol and curcumin individually (at the same doses as the combination) provided significant, albeit lower levels of protection in this model as well (Majumdar et al. 2009). Table 2 summarizes the animal models used to investigate resveratrol and colorectal cancer.

\section{Liver cancer}

Liver cancer, or hepatocellular carcinoma (HCC), is one of the most deadly forms of cancer, and its incidence has been increasing worldwide (Llovet et al. 2003). Risk factors for HCC include hepatitis, alcoholism, and high-fat diet consumption (El-Serag et al. 2006, Alter 2007). Animal models used to study the effects of resveratrol on hepatic tumors include transplantation of liver cancer cells into animal host and carcinogenic promotion of tumor formation. In adult male Wistar rats injected with AH-130 Yoshida ascites hepatoma cells, daily resveratrol treatment $(1 \mathrm{mg} / \mathrm{kg}$ BW; i.p. injection) starting at cell implantation reduced the number of tumor cells after 7 days compared with untreated rats injected with the hepatoma cells. Though, it is important to point out that tumor volume was unchanged by resveratrol treatment (Carbo et al. 1999).

Multiple studies in rats have used diethylnitrosamine (DENA) injection followed by tumor promotion with phenobarbital to induce HCC in the animals. In one of these studies, Bishayee \& Dhir (2009) gave resveratrol to adult female Sprague-Dawley rats $(0.06,0.12$, or $0.36 \%$ diet; daily intake calculated to be 50,100 , or $300 \mathrm{mg} / \mathrm{kg}$ BW) starting 4 weeks before tumor initiation and continued for 16 weeks after initiation. Resveratrol supplementation at 100 and $300 \mathrm{mg} / \mathrm{kg}$ BW reduced the appearance and multiplicity of hepatocyte nodules at the end of the study compared with DENA-treated animals that did not receive resveratrol. Cellular architecture of the liver tissue was also improved by resveratrol treatment at $300 \mathrm{mg} / \mathrm{kg}$ BW. In all three doses of resveratrol treatment, there was a decrease in hepatic cellular proliferation as indicated by reduced expression of proliferating cell nuclear antigen (PCNA). In the livers of the two higher doses of resveratrol-treated animals, there were also significant increases in Bax expression and decreases in $B c l 2$ expression, signifying facilitation of apoptosis by resveratrol. Furthermore, resveratrol at higher doses decreased lipid peroxidation and protein carbonyl content in livers compared with control DENA-injected rats, indicating that resveratrol might act as a free radical scavenger and decrease the incidence of tumor formation (Bishayee et al. 2010a). Resveratrol supplementation also caused an increase in hepatic expression of NFE2-related factor 2 (Nrf2 (Nfe212); Bishayee et al. 2010a). Increased expression of $N f r 2$, a transcription factor involved in the expression of antioxidant genes, suggests that resveratrol may exert an antioxidant effect in the liver of DENAinjected animals. Lastly, in a dose-dependent manner, resveratrol reduced the expression of heat-shock protein 70 and COX2, as well as decreased DENA-induced translocation of NF- $\mathrm{KB}$ to the nucleus, suggesting that resveratrol is having an anti-inflammatory effect in this model (Bishayee et al. 2010b). In a separate study, the same group found that resveratrol reduced tumor multiplicity in a dose-dependent manner compared with control DENA-treated animals 14 weeks after tumor initiation. In this study, the lowest dose of resveratrol $(50 \mathrm{mg} / \mathrm{kg}$ BW) also significantly decreased the nodule multiplicity (Luther et al. 2011). In a more recent study, Rajasekaran et al. (2011) have investigated the ability of resveratrol to prevent or treat HCC in 6- to 8-week-old male Wistar rats by treating animals daily with resveratrol $(20 \mathrm{mg} / \mathrm{kg} \mathrm{BW}$; oral gavage) for either 15 days starting at the DENA injection or for 15 days after the development of HCC. In both the early and advance stages of HCC, resveratrol treatment increased the expression of apoptotic markers and decreased the expression of anti-apoptotic markers. Resveratrol treatment at both time points also reduced cell crowding and alteration in cellular architecture as well as decreased liver size compared with control rats treated with DENA (Rajasekaran et al. 2011). Lin et al. (2012) evaluated the effects of resveratrol treatment on the precancerous stage of liver carcinogenesis in 12-month-old male hepatitis $B$ virus $\mathrm{X}$ protein $(\mathrm{HBX})$ transgenic mice that spontaneously develop HCC at older ages. Resveratrol supplementation $(0.024 \%$ diet; daily intake calculated to be $30 \mathrm{mg} / \mathrm{kg}$ BW) for 4 months significantly reduced the incidence of HCC by 5.3 -fold and increased latency to tumor formation. The results from liver cancer models have been consistently positive, indicating a potential benefit for resveratrol in HCC prevention and/or therapy.

In addition to regulation of liver cancer function, resveratrol may also influence metastasis to the liver from other primary cancers. Salado et al. (2011) used B16 melanoma (B16M) cells to study the effects of resveratrol treatment on hepatic metastasis caused in large part by the production of proinflammatory cytokines. Six- to eightweek-old male C57BL/6J mice were given a daily oral dose of resveratrol $(1 \mathrm{mg} / \mathrm{kg} \mathrm{BW})$ from the day of intrasplenic

Published by Bioscientifica Ltd. 
injection of B16M cells through 12 days after injection. Resveratrol treatments reduced hepatic metastasis volume and metastasis number compared with vehicle control mice given B16M cells. A summary of the methods and findings are given in Table 3.

\section{Pancreatic cancer}

Risk for pancreatic cancer is linked to obesity, highfat diet, and consumption of meat products (Olsen et al. 1989, Baghurst et al. 1991). Because so many pancreatic carcinomas are diagnosed at late, treatment-refractory stages, prognosis for patients with pancreatic cancer is generally poor. Clearly, there is a need for effective treatment alternatives for pancreatic cancer. A few researchers have looked at the in vivo effects of resveratrol on pancreatic cancer (Table 4). Oi et al. (2010) injected 6- to 8-week old Swiss nude mice with human pancreatic carcinoma cells (PaCa-2) to promote pancreatic tumor xenograft formation. Resveratrol was given five times a week by oral gavage ( 10 or $50 \mathrm{mg} / \mathrm{kg} \mathrm{BW}$ ) for 2 weeks before MIA PaCa-2 injection and then continued throughout the experiment until tumor volumes reached $1 \mathrm{~cm}^{3}$. Resveratrol reduced tumor size and number in a dosedependent manner compared with animals dosed with vehicle control. Resveratrol also inhibited the activity of an inflammatory enzyme, leukotriene $\mathrm{A}_{4}$ hydrolase (Oi et al. 2010). In a similar study, Harikumar et al. (2010) injected MIA PaCa-2 cells into 4-week-old male mice and then resveratrol was given daily $(40 \mathrm{mg} / \mathrm{kg} \mathrm{BW})$ for a 4 week duration starting 1 week after the cells were injected. They found that resveratrol treatment significantly decreased tumor growth compared with vehicle-treated mice. Combination treatment of resveratrol with gemcitabine further enhanced protection as well. In 4- to 6-week old BALB/c nude mice treated five times a week with resveratrol for 6 weeks $(20,40$, or $60 \mathrm{mg} / \mathrm{kg}$ BW by gavage) starting 1 week after tumor cell injection, resveratrol reduced tumor growth caused by the injection of PANC-1 cells (human pancreatic carcinoma, epitheliallike cells) in a dose-dependent manner compared with control mice (Roy et al. 2011). Tumor tissues from resveratrol-treated mice also showed increased apoptosis and decreased proliferation compared with tumor tissue from vehicle-treated mice. This was accompanied by the inhibition of PI3K and Akt phosphorylation leading to an increase in the activation of the transcription factor Forkhead box O (FOXO). Activation of FOXO results in the expression of genes involved in cell-cycle arrest, indicating that resveratrol reduced tumor growth through its effects on the cell cycle (Roy et al. 2011). In 8-week-old Kras ${ }^{G 12 D}$ mice that spontaneously develop pancreatic tumors, resveratrol treatment over a 10-month period for five times a week ( $40 \mathrm{mg} / \mathrm{kg}$ BW by oral gavage) reduced pancreatic lesions compared with $\mathrm{Kras}^{G 12 D}$ that did not receive resveratrol treatment, indicating that resveratrol reduced spontaneous pancreatic tumors (Shankar et al. 2011). The use of all animal models of pancreatic cancer has not shown that resveratrol supplementation is beneficial, however. One study evaluated resveratrol treatment $(0.001 \%$ in diet) in 6-week-old male Syrian hamsters during and after tumor initiation via $\mathrm{N}$-nitrosobis(2-oxopropyl)amine injection (Kuroiwa et al. 2006). Resveratrol did not affect the formation of hyperplasias or adenocarcinomas in either treatment stage. Regardless, data at this point suggest that resveratrol either positively influences or does not significantly impact pancreatic cancer outcomes in rodent models.

\section{Prostate cancer}

In men, prostate cancer is a leading cause of cancer-related death in USA (Siegel et al. 2013). Diet and lifestyle may play a major role in the development of prostate cancer (Wolk 2005), making a supplement such as resveratrol a promising candidate for prostate cancer chemoprevention. Relatively few in vivo studies, however, have been conducted that investigate the effects of resveratrol on prostate cancer prevention and treatment. Two studies have used rodent models of spontaneous prostate tumor formation to investigate resveratrol's protective abilities: the transgenic adenocarcinoma of mouse prostate (TRAMP) and the transgenic rat for adenocarcinoma of prostate (TRAP) models (Harper et al. 2007, Seeni et al. 2008). Three additional studies have used xenograft models to study resveratrol's potential effects (Seeni et al. 2008, Wang et al. 2008, Dias et al. 2013).

Harper et al. (2007) administered resveratrol (0.0625\% in diet) to 5-week-old TRAMP mice daily for 23 weeks and then observed tumor formation in the urogenital tract of the mice. Resveratrol-fed mice had a significantly reduced percentage of Grade 6, poorly differentiated tumors compared with control diet-fed mice. Grade 4 lesions were more common in resveratrol-treated mice than control diet-fed, indicating that resveratrol slowed down tumor progression to this stage (Harper et al. 2007). There were, however, no differences in tumor numbers per animal, tumor weight, latency to tumor formation, or metastases between resveratrol treated and control animals (Harper et al. 2007). Further, at 12 weeks of age

Published by Bioscientifica Ltd 
after 7 weeks on the resveratrol diet, TRAMP mice showed reduced cellular proliferation in the dorsolateral and ventral prostate compared with control diet mice (Harper et al. 2007).

When resveratrol was administered daily to TRAP rats for 7 weeks $(0.005,0.01$, or $0.02 \%$ in drinking water), neoplastic lesion development was significantly reduced in the ventral and lateral lobes of the prostate compared with control-treated TRAP rats (Seeni et al. 2008). There were, however, no significant differences in adenocarcinoma incidence between resveratrol-treated and control TRAP rats in either the ventral or lateral prostate (Seeni et al. 2008). Protein expression of androgen receptor (AR) was also measured in the prostate of TRAP rats; resveratrol treatment at all three doses significantly decreased AR expression in the ventral prostate compared with control animals, suggesting a possible mechanism through which resveratrol may have chemopreventative effects (Seeni et al. 2008). Within this same paper, Seeni et al. injected rat prostate cancer cells (PLS30 cells) into male athymic CD-1 nude mice at 6 weeks of age. Mice were then treated with or without resveratrol $(0.01$ or $0.02 \%$ in drinking water) from 1 week after the injection until they were killed at 6 weeks after the injection. Tumor volume and metastatic foci in the lungs were measured; neither resveratrol dose significantly affected either parameter compared with those mice not treated with resveratrol. Seeni et al. (2008) hypothesized that this was possibly due to the lack of AR protein in the PLS30 cells.

Two other studies have focused on the effects of resveratrol in human prostate cancer cells xenograft models. In both, androgen responsive-LNCaP human prostate cancer cells were injected s.c. into male mice following pre-treatment with resveratrol. Wang et al. (2008) administered resveratrol to 5-week-old BALB/ cAnNCr- $n u / n u$ mice $(0.005$ or $0.01 \%$ in diet, daily) for 2 weeks before cell injection through 7 weeks after injection. After injection, animals were palpitated for tumor growth weekly; resveratrol at both doses in the diet significantly delayed tumor growth by 3 weeks (both doses) and 4 weeks (higher dose only) post injection compared with control diet mice; however, by 7 weeks, there were no differences in tumor volume (Wang et al. 2008). No differences in cell proliferation, measured by PCNA, were found between the resveratrol-treated and untreated groups. Interestingly, the resveratrol-treated animals showed significantly lower levels of apoptosis, measured by ApopTag, and there was increased microvessel formation (angiogenesis), measured by platelet/endothelial cell adhesion molecule 1 staining, in the higher resveratrol dose mice compared with control-fed mice (Wang et al. 2008). Deceased apoptosis and increased angiogenesis could lead to long-term complications and worse outcomes. A separate study used similar tumor cells in 6- to 7-week-old Fox $n 1^{\text {nu }}$ mice (Dias et al. 2013). Mice were treated with $50 \mathrm{mg} / \mathrm{kg}$ of resveratrol via oral gavage every other day for 2 weeks before tumor cell injection through 5 weeks after injection. Resveratrol significantly decreased tumor formation and progression, as assessed by caliper measurements, compared with control mice that did not receive resveratrol. Resveratrol also caused a decrease in serum interleukin 6 (IL6; Dias et al. 2013). As part of the same experiment, Dias et al. (2013) also studied the effects of two resveratrol analogs that could have better bioavailability (trimethoxy-resveratrol and piceatannol) and found that both decreased tumor volume and IL6 in mouse serum. These compounds should be tested in additional studies. Data from these models suggest that resveratrol may have some positive impacts on prostate tumor formation and progression, but it may have some unwanted effects on angiogenesis around the tumors. Additional work needs to be done in this area. A summary of the prostate cancer studies is provided in Table 5 .

\section{Discussion}

Although there is some in vivo evidence for the use of resveratrol as a chemopreventative agent, there is still much more research that needs to be done on tumor induction methods and dose selection as well as age- and sex-specific effects of resveratrol supplementation. Tables $1,2,3,4$ and 5 highlight the differences in the in vivo models used, including cancer models, methods of tumor initiation, strain, species, sex, method/timing of resveratrol administration, and dose of resveratrol. The tables show that there is no consistent technique used for resveratrol administration. Resveratrol delivery (large single daily dose by oral gavage or injection vs small doses throughout the day/night when resveratrol is provided in food or drinking water) could have critical effects on cancer outcomes due to the quick absorption and metabolism of resveratrol. Furthermore, many papers did not measure or report circulating resveratrol levels which makes comparison across strains, species, and studies nearly impossible. The source (purified from Japanese knotweed, chemically synthesized, etc.) and purity of resveratrol were not reported in all papers and could also play a role in inconsistent effects observed in the studies. It is also important to take into account the fact that doses in animals generally cannot be directly

Published by Bioscientifica Ltd. 
translated to humans, for example, it may be important to normalize dosing to body surface area as opposed to BW (Reagan-Shaw et al. 2008).

There is little evidence from animal or human studies that resveratrol can serve as a viable treatment option once tumors are already formed, so it is not likely that resveratrol can be used as an alternative for the traditional forms of cancer treatment in the near future. Further, resveratrol supplementation had no effect on spontaneous neoplasia formation in WT C57BL/6 male mice fed resveratrol in their diet ( 0.01 or $0.04 \%)$ from 12 months of age through the remainder of their lives (Pearson et al. 2008). Also, resveratrol does not appear to target the cellular structures involved in proliferation such as microtubules or nucleotide synthetic enzymes that many of the traditional chemotherapeutics target; therefore resveratrol is unlikely to be efficacious as a primary anticancer agent. Rather, resveratrol appears to maintain cellular homeostasis in part by protecting cells against oxidative injury and other cancer-causing perturbations. The addition of resveratrol to standard chemotherapeutic regimens may therefore be helpful in preventing the development of secondary malignancies that result from mutagenic effects of chemotherapy and radiotherapy (Kinghorn et al. 2004, Aziz et al. 2005, Le Corre et al. 2005, Lee \& Lee 2006, Khan et al. 2008, Kundu \& Surh 2008, Dennis et al. 2009, Seehusen et al. 2010, Newhauser \& Durante 2011, Szekeres et al. 2011). Resveratrol may also help to prevent other long-term morbidities associated with anti-cancer therapy, such as cardiac myocyte toxicity and subsequent heart failure from exposure to anthracyclines such as doxorubicin (Tatlidede et al. 2009). Thus, although resveratrol is not likely to be a primary treatment for cancer, in addition to its potential role in primary cancer prevention by reducing carcinogenesis for primary malignancies, it may have a role in the prevention of secondary malignancies and/or other toxic effects of traditional chemotherapeutic agents. As a result, it is important to emphasize further resveratrol supplementation as a way to prevent the development of cancer and disease and as a supplement used in conjugation with traditional chemotherapeutics.

After oral administration, trans-resveratrol is quickly conjugated into glucuronides and sulfates (Andlauer $e t a l$. 2000, De Santi et al. 2000, Soleas et al. 2001, Yu et al. 2002). Because the bioavailability of trans-resveratrol after oral administration is low (Wenzel \& Somoza 2005), researchers have recently started to investigate the effects of resveratrol derivatives with higher bioavailability (Szekeres et al. 2011, Dias et al. 2013). Also, some of the efforts to improve resveratrol's bioavailability have focused on combination therapy with other compounds that may prevent or delay conjugation of resveratrol. Piperine, a compound found in black pepper, can inhibit glucuronidation (Reen et al. 1993, Shoba et al. 1998). In mice, piperine significantly increased the serum levels of resveratrol after oral administration of both compounds (Johnson et al. 2011). Other studies have focused on the synergistic effects of resveratrol and other naturally occurring compounds such as melatonin, tea polyphenols, and quercetin on cancer models; for a thorough review of these studies see Singh et al. (2013).

Epidemiological studies have found strong correlations between obesity and certain types of cancers including breast, endometrial, colorectal, pancreatic, and HCCs (Moller et al. 1994, Galanis et al. 1998, Silverman et al. 1998, Gapstur et al. 2000, Trentham-Dietz et al. 2000, Vainio et al. 2002, Calle et al. 2003). Excessive amounts of body fat can cause changes in hormone and protein levels that result in cellular deregulation, and therefore possibly cancer. Therefore, targeting obesity may be a way to prevent and/or lower risk of cancer development. Resveratrol is an important molecule to consider in this area of cancer prevention since it has been shown to have many positive effects on animal models of obesity and high-fat diet. In animal studies, resveratrol was found to prolong survival and decrease fat mass in mice fed a high-fat diet (Baur et al. 2006, Lagouge et al. 2006). Resveratrol treatment also decreased hyperglycemia in a model of diet-induced diabetes as well as improved insulin sensitivity when insulin resistance has developed due to increased fat mass (Ramadori et al. 2009, Kang et al. 2012). In some initial clinical trials, resveratrol supplementation improved glucose regulation in aged subjects with impaired glucose tolerance and improved homeostatic model assessment index in obese men (Timmers et al. 2011, Crandall et al. 2012). Also, in two separate studies looking at resveratrol supplementation in type 2 diabetics, resveratrol improved insulin sensitivity and HbA1c measurements (Brasnyo et al. 2011, Bhatt et al. 2012). Other groups were unable to show improvements in insulin sensitivity or glucose regulation with resveratrol treatment. In both normal weight and obese subjects, resveratrol use was unable to improve insulin sensitivity and glucose uptake into tissues when measured by hyperinsulinemic-euglycemic clamp (Yoshino et al. 2012, Poulsen et al. 2013). Similar to the animal studies looking at resveratrol and cancer, differences in the amount and length of resveratrol treatment could be a factor in differences observed between studies. However,

Published by Bioscientifica Ltd. 
there is some promising evidence that resveratrol can improve metabolic outcomes and could have a major impact on overall health, including decreasing cancer risk.

\section{Conclusion}

Research has shown that resveratrol supplementation could potentially have many positive health benefits including decreased cancer risk. Yet, there are limited clinical trials with small sample sizes, and animal models have had mixed results. There is a need for more extensive and consistent studies in animal models. Little evidence exists that resveratrol can be used effectively to treat preexisting tumors (that were not implanted cells); therefore the most promising use of resveratrol is most likely as a cancer preventative agent. Determining the efficacy and appropriateness for resveratrol as a cancer preventive or anti-cancer agent is likely to be an area of emphasis for future research studies and clinical trials. Resveratrol may impact certain tumor types more so than others, based on its proposed mechanisms of action and different oncogenic pathways being tumor-specific. In addition, much work needs to be done on optimizing the bioavailability of the drug and determining its pharmacokinetic, pharmacodynamics, and safety profile in different patient populations (e.g. adults vs pregnant women vs children).

\section{Declaration of interest}

The authors declare that there is no conflict of interest that could be perceived as prejudicing the impartiality of the review.

\section{Funding}

K J Pearson was supported by the U.S. National Institutes of Health through the National Cancer Institute (R03 CA165086-01A1) and an Institutional Development Award (IDeA) from the National Institute of General Medical Sciences (8 P20 GM103527-05). L G Carter was supported by an NIH training grant from the National Institute of Diabetes and Digestive and Kidney Diseases (DK07778)

\section{Acknowledgements}

The authors thank Joseph Baur and Jonathan Schneider for critical review of the manuscript. We intended to include most of the vast literature on the in vivo studies of resveratrol and breast, colorectal, liver, pancreatic, and prostate cancers. However, we are aware of and apologize to any authors whose work was omitted.

\section{References}

Afaq F, Adhami VM \& Ahmad N 2003 Prevention of short-term ultraviolet $\mathrm{B}$ radiation-mediated damages by resveratrol in SKH-1 hairless mice.

http://erc.endocrinology-journals.org DOI: 10.1530/ERC-13-0171
(C) 2014 The authors Printed in Great Britain
Toxicology and Applied Pharmacology 186 28-37. (doi:10.1016/S0041008X(02)00014-5)

Alfaras I, Juan ME \& Planas JM 2010 Tans-resveratrol reduces precancerous colonic lesions in dimethylhydrazine-treated rats. Journal of Agricultural and Food Chemistry 58 8104-8110. (doi:10.1021/jf100702x)

Alter MJ 2007 Epidemiology of hepatitis C virus infection. World Journal of Gastroenterology 13 2436-2441.

Andlauer W, Kolb J, Siebert K \& Furst P 2000 Assessment of resveratrol bioavailability in the perfused small intestine of the rat. Drugs Under Experimental and Clinical Research 26 47-55.

Aziz MH, Reagan-Shaw S, Wu J, Longley BJ \& Ahmad N 2005 Chemoprevention of skin cancer by grape constituent resveratrol: relevance to human disease? FASEB Journal 19 1193-1195.

Baghurst PA, McMichael AJ, Slavotinek AH, Baghurst KI, Boyle P \& Walker AM 1991 A case-control study of diet and cancer of the pancreas. American Journal of Epidemiology 134 167-179.

Banerjee S, Bueso-Ramos C \& Aggarwal BB 2002 Suppression of 7,12dimethylbenz $(a)$ anthracene-induced mammary carcinogenesis in rats by resveratrol: role of nuclear factor- $\mathrm{k}$, cyclooxygenase 2 , and matrix metalloprotease 9. Cancer Research 62 4945-4954.

Baur JA \& Sinclair DA 2006 Therapeutic potential of resveratrol: the in vivo evidence. Nature Reviews. Drug Discovery 5 493-506. (doi:10.1038/ nrd2060)

Baur JA, Pearson KJ, Price NL, Jamieson HA, Lerin C, Kalra A, Prabhu VV, Allard JS, Lopez-Lluch G, Lewis K et al. 2006 Resveratrol improves health and survival of mice on a high-calorie diet. Nature 444 337-342. (doi:10.1038/nature05354)

Benitez DA, Hermoso MA, Pozo-Guisado E, Fernandez-Salguero PM \& Castellon EA 2009 Regulation of cell survival by resveratrol involves inhibition of NFKB-regulated gene expression in prostate cancer cells. Prostate 69 1045-1054. (doi:10.1002/pros.20953)

Bhat KP \& Pezzuto JM 2002 Cancer chemopreventive activity of resveratrol. Annals of the New York Academy of Sciences 957 210-229. (doi:10.1111/j. 1749-6632.2002.tb02918.x)

Bhat KP, Lantvit D, Christov K, Mehta RG, Moon RC \& Pezzuto JM 2001 Estrogenic and antiestrogenic properties of resveratrol in mammary tumor models. Cancer Research 61 7456-7463.

Bhatt JK, Thomas S \& Nanjan MJ 2012 Resveratrol supplementation improves glycemic control in type 2 diabetes mellitus. Nutrition Research 32 537-541. (doi:10.1016/j.nutres.2012.06.003)

Bishayee A \& Dhir N 2009 Resveratrol-mediated chemoprevention of diethylnitrosamine-initiated hepatocarcinogenesis: inhibition of cell proliferation and induction of apoptosis. Chemico-Biological Interactions 179 131-144. (doi:10.1016/j.cbi.2008.11.015)

Bishayee A, Barnes KF, Bhatia D, Darvesh AS \& Carroll RT 2010a Resveratrol suppresses oxidative stress and inflammatory response in diethylnitrosamine-initiated rat hepatocarcinogenesis. Cancer Prevention Research 3 753-763. (doi:10.1158/1940-6207.CAPR-09-0171)

Bishayee A, Waghray A, Barnes KF, Mbimba T, Bhatia D, Chatterjee M \& Darvesh AS $2010 b$ Suppression of the inflammatory cascade is implicated in resveratrol chemoprevention of experimental hepatocarcinogenesis. Pharmaceutical Research 27 1080-1091. (doi:10.1007/ s11095-010-0144-4)

Bove K, Lincoln DW \& Tsan MF 2002 Effect of resveratrol on growth of 4T1 breast cancer cells in vitro and in vivo. Biochemical and Biophysical Research Communications 291 1001-1005. (doi:10.1006/bbrc.2002. 6554)

Bowers JL, Tyulmenkov VV, Jernigan SC \& Klinge CM 2000 Resveratrol acts as a mixed agonist/antagonist for estrogen receptors $\alpha$ and $\beta$. Endocrinology 141 3657-3667.

Bradamante S, Barenghi L \& Villa A 2004 Cardiovascular protective effects of resveratrol. Cardiovascular Drug Reviews 22 169-188. (doi:10.1111/j. 1527-3466.2004.tb00139.x)

Brasnyo P, Molnar GA, Mohas M, Marko L, Laczy B, Cseh J, Mikolas E, Szijarto IA, Merei A, Halmai R et al. 2011 Resveratrol improves insulin sensitivity, reduces oxidative stress and activates the Akt pathway in

Published by Bioscientifica Ltd. 
type 2 diabetic patients. British Journal of Nutrition 106 383-389. (doi:10.1017/S0007114511000316)

Brown VA, Patel KR, Viskaduraki M, Crowell JA, Perloff M, Booth TD, Vasilinin G, Sen A, Schinas AM, Piccirilli G et al. 2010 Repeat dose study of the cancer chemopreventive agent resveratrol in healthy volunteers: safety, pharmacokinetics, and effect on the insulin-like growth factor axis. Cancer Research 70 9003-9011. (doi:10.1158/0008-5472. CAN-10-2364)

Burns J, Yokota T, Ashihara H, Lean ME \& Crozier A 2002 Plant foods and herbal sources of resveratrol. Journal of Agricultural and Food Chemistry 50 3337-3340. (doi:10.1021/jf0112973)

Calle EE, Rodriguez C, Walker-Thurmond K \& Thun MJ 2003 Overweight, obesity, and mortality from cancer in a prospectively studied cohort of U.S. adults. New England Journal of Medicine 348 1625-1638. (doi:10.1056/NEJMoa021423)

Carbo N, Costelli P, Baccino FM, Lopez-Soriano FJ \& Argiles JM 1999 Resveratrol, a natural product present in wine, decreases tumour growth in a rat tumour model. Biochemical and Biophysical Research Communications 254 739-743. (doi:10.1006/bbrc.1998.9916)

Castillo-Pichardo L, Cubano LA \& Dharmawardhane S 2013 Dietary grape polyphenol resveratrol increases mammary tumor growth and metastasis in immunocompromised mice. BMC Complementary and Alternative Medicine 13 6. (doi:10.1186/1472-6882-13-6)

Chatterjee M, Das S, Janarthan M \& Ramachandran HK 2011 Role of 5-lipoxygenase in resveratrol mediated suppression of 7,12-dimethylbenz $(\alpha)$ anthracene-induced mammary carcinogenesis in rats. European Journal of Pharmacology 668 99-106. (doi:10.1016/j.ejphar.2011.06. 039)

Chow HH, Garland LL, Hsu CH, Vining DR, Chew WM, Miller JA, Perloff M, Crowell JA \& Alberts DS 2010 Resveratrol modulates drug- and carcinogen-metabolizing enzymes in a healthy volunteer study. Cancer Prevention Research 3 1168-1175. (doi:10.1158/1940-6207.CAPR-09. 0155)

Clement MV, Hirpara JL, Chawdhury SH \& Pervaiz S 1998 Chemopreventive agent resveratrol, a natural product derived from grapes, triggers CD95 signaling-dependent apoptosis in human tumor cells. Blood 92 996-1002.

Crandall JP, Oram V, Trandafirescu G, Reid M, Kishore P, Hawkins M, Cohen HW \& Barzilai N 2012 Pilot study of resveratrol in older adults with impaired glucose tolerance. Journals of Gerontology. Series A, Biological Sciences and Medical Sciences 67 1307-1312. (doi:10.1093/ gerona/glr235)

Csaki C, Mobasheri A \& Shakibaei M 2009 Synergistic chondroprotective effects of curcumin and resveratrol in human articular chondrocytes: inhibition of IL-1 $\beta$-induced NF- $\kappa$ B-mediated inflammation and apoptosis. Arthritis Research \& Therapy 11 R165. (doi:10.1186/ar2850)

Dennis T, Fanous M \& Mousa S 2009 Natural products for chemopreventive and adjunctive therapy in oncologic disease. Nutrition and Cancer 61 587-597. (doi:10.1080/01635580902825530)

De Santi C, Pietrabissa A, Spisni R, Mosca F \& Pacifici GM 2000 Sulphation of resveratrol, a natural compound present in wine, and its inhibition by natural flavonoids. Xenobiotica 30 857-866. (doi:10.1080/ 004982500433282)

DeSantis C, Howlader N, Cronin KA \& Jemal A $2011 a$ Breast cancer incidence rates in U.S. women are no longer declining. Cancer Epidemiology, Biomarkers \& Prevention 20 733-739. (doi:10.1158/10559965.EPI-11-0061)

DeSantis C, Siegel R, Bandi P \& Jemal A 2011b Breast cancer statistics, 2011. CA: A Cancer Journal for Clinicians 61 409-418. (doi:10.3322/caac. 20134)

Dias SJ, Li K, Rimando AM, Dhar S, Mizuno CS, Penman AD \& Levenson AS 2013 Trimethoxy-resveratrol and piceatannol administered orally suppress and inhibit tumor formation and growth in prostate cancer xenografts. Prostate 73 1135-1146. (doi:10.1002/pros. 22657)
Doll R \& Peto R 1981 The causes of cancer: quantitative estimates of avoidable risks of cancer in the United States today. Journal of the National Cancer Institute 66 1191-1308.

Dong Z 2003 Molecular mechanism of the chemopreventive effect of resveratrol. Mutation Research 523-524 145-150. (doi:10.1016/S00275107(02)00330-5)

El-Serag HB, Hampel H \& Javadi F 2006 The association between diabetes and hepatocellular carcinoma: a systematic review of epidemiologic evidence. Clinical Gastroenterology and Hepatology 4 369-380. (doi:10.1016/j.cgh.2005.12.007)

Galanis DJ, Kolonel LN, Lee J \& Le Marchand L 1998 Anthropometric predictors of breast cancer incidence and survival in a multi-ethnic cohort of female residents of Hawaii, United States. Cancer Causes \& Control 9 217-224. (doi:10.1023/A:1008842613331)

Gapstur SM, Gann PH, Lowe W, Liu K, Colangelo L \& Dyer A 2000 Abnormal glucose metabolism and pancreatic cancer mortality. Journal of American Medical Association 283 2552-2558. (doi:10.1001/ jama.283.19.2552)

Garvin S, Ollinger K \& Dabrosin C 2006 Resveratrol induces apoptosis and inhibits angiogenesis in human breast cancer xenografts in vivo. Cancer Letters 231 113-122. (doi:10.1016/j.canlet.2005.01.031)

Goldberg DM, Yan J, Ng E, Diamandis EP, Karumanchiri A, Soleas G \& Waterhouse AL 1995 A global survey of trans-resveratrol concentrations in commercial wines. American Journal of Enology and Viticulture $\mathbf{4 6}$ 159-165.

Goldberg DM, Yan J \& Soleas GJ 2003 Absorption of three wine-related polyphenols in three different matrices by healthy subjects. Clinical Biochemistry 36 79-87. (doi:10.1016/S0009-9120(02)00397-1)

Harikumar KB, Kunnumakkara AB, Sethi G, Diagaradjane P, Anand P, Pandey MK, Gelovani J, Krishnan S, Guha S \& Aggarwal BB 2010 Resveratrol, a multitargeted agent, can enhance antitumor activity of gemcitabine in vitro and in orthotopic mouse model of human pancreatic cancer. International Journal of Cancer $\mathbf{1 2 7}$ 257-268.

Harper CE, Patel BB, Wang J, Arabshahi A, Eltoum IA \& Lamartiniere CA 2007 Resveratrol suppresses prostate cancer progression in transgenic mice. Carcinogenesis 28 1946-1953. (doi:10.1093/carcin/bgm144)

Holmes-McNary M \& Baldwin AS Jr 2000 Chemopreventive properties of trans-resveratrol are associated with inhibition of activation of the $\mathrm{I} \kappa \mathrm{B}$ kinase. Cancer Research $603477-3483$.

Howells LM, Berry DP, Elliott PJ, Jacobson EW, Hoffmann E, Hegarty B, Brown K, Steward WP \& Gescher AJ 2011 Phase I randomized, doubleblind pilot study of micronized resveratrol (SRT501) in patients with hepatic metastases - safety, pharmacokinetics, and pharmacodynamics. Cancer Prevention Research 4 1419-1425. (doi:10.1158/19406207.CAPR-11-0148)

Hung LM, Chen JK, Huang SS, Lee RS \& Su MJ 2000 Cardioprotective effect of resveratrol, a natural antioxidant derived from grapes. Cardiovascular Research 47 549-555. (doi:10.1016/S0008-6363(00)00102-4)

Jacoby RF, Marshall DJ, Newton MA, Novakovic K, Tutsch K, Cole CE, Lubet RA, Kelloff GJ, Verma A, Moser AR et al. 1996 Chemoprevention of spontaneous intestinal adenomas in the Apc Min mouse model by the nonsteroidal anti-inflammatory drug piroxicam. Cancer Research $\mathbf{5 6}$ 710-714.

Jacoby RF, Seibert K, Cole CE, Kelloff G \& Lubet RA 2000 The cyclooxygenase- 2 inhibitor celecoxib is a potent preventive and therapeutic agent in the min mouse model of adenomatous polyposis. Cancer Research $605040-5044$.

Jang M \& Pezzuto JM 1999 Cancer chemopreventive activity of resveratrol. Drugs Under Experimental and Clinical Research 25 65-77.

Jang M, Cai L, Udeani GO, Slowing KV, Thomas CF, Beecher CW, Fong HH, Farnsworth NR, Kinghorn AD, Mehta RG et al. 1997 Cancer chemopreventive activity of resveratrol, a natural product derived from grapes. Science 275 218-220. (doi:10.1126/science.275.5297.218)

Johnson JJ, Nihal M, Siddiqui IA, Scarlett CO, Bailey HH, Mukhtar H \& Ahmad N 2011 Enhancing the bioavailability of resveratrol by 
combining it with piperine. Molecular Nutrition \& Food Research 55 1169-1176. (doi:10.1002/mnfr.201100117)

Kaldas MI, Walle UK \& Walle T 2003 Resveratrol transport and metabolism by human intestinal Caco-2 cells. Journal of Pharmacy and Pharmacology 55 307-312. (doi:10.1211/002235702612)

Kalra N, Roy P, Prasad S \& Shukla Y 2008 Resveratrol induces apoptosis involving mitochondrial pathways in mouse skin tumorigenesis. Life Sciences 82 348-358. (doi:10.1016/j.lfs.2007.11.006)

Kang L, Heng W, Yuan A, Baolin L \& Fang H 2010 Resveratrol modulates adipokine expression and improves insulin sensitivity in adipocytes: relative to inhibition of inflammatory responses. Biochimie 92 789-796. (doi:10.1016/j.biochi.2010.02.024)

Kang W, Hong HJ, Guan J, Kim DG, Yang EJ, Koh G, Park D, Han CH, Lee YJ \& Lee DH 2012 Resveratrol improves insulin signaling in a tissuespecific manner under insulin-resistant conditions only: in vitro and in vivo experiments in rodents. Metabolism 61 424-433. (doi:10.1016/ j.metabol.2011.08.003)

Khan N, Afaq F \& Mukhtar H 2008 Cancer chemoprevention through dietary antioxidants: progress and promise. Antioxidants \& Redox Signaling 10 475-510. (doi:10.1089/ars.2007.1740)

Kinghorn AD, Su BN, Jang DS, Chang LC, Lee D, Gu JQ, Carcache-Blanco EJ, Pawlus AD, Lee SK, Park EJ et al. 2004 Natural inhibitors of carcinogenesis. Planta Medica 70 691-705. (doi:10.1055/s-2004827198)

Kiraly-Veghely Z, Tyihak E, Albert L, Nemeth ZI \& Katay G 1998 Identification and measurement of resveratrol and formaldehyde in parts of white and blue grape berries. Acta Biologica Hungarica 49 281-289.

Kopp P 1998 Resveratrol, a phytoestrogen found in red wine. A possible explanation for the conundrum of the 'French paradox'? European Journal of Endocrinology 138 619-620. (doi:10.1530/eje.0. 1380619)

Kundu JK \& Surh YJ 2008 Cancer chemopreventive and therapeutic potential of resveratrol: mechanistic perspectives. Cancer Letters 269 243-261. (doi:10.1016/j.canlet.2008.03.057)

Kuroiwa Y, Nishikawa A, Kitamura Y, Kanki K, Ishii Y, Umemura T \& Hirose M 2006 Protective effects of benzyl isothiocyanate and sulforaphane but not resveratrol against initiation of pancreatic carcinogenesis in hamsters. Cancer Letters 241 275-280. (doi:10.1016/j.canlet. 2005.10.028)

Lagouge M, Argmann C, Gerhart-Hines Z, Meziane H, Lerin C, Daussin F, Messadeq N, Milne J, Lambert P, Elliott P et al. 2006 Resveratrol improves mitochondrial function and protects against metabolic disease by activating SIRT1 and PGC-1 $\alpha$. Cell 127 1109-1122. (doi:10.1016/j.cell.2006.11.013)

Langcake P \& Pryce RJ 1976 Production of resveratrol by vitis-vinifera and other members of vitaceae as a response to infection or injury. Physiological Plant Pathology 9 77-86. (doi:10.1016/0048-4059(76) 90077-1)

Le Corre L, Chalabi N, Delort L, Bignon YJ \& Bernard-Gallon DJ 2005 Resveratrol and breast cancer chemoprevention: molecular mechanisms. Molecular Nutrition \& Food Research 49 462-471. (doi:10.1002/mnfr.200400094)

Lee KW \& Lee HJ 2006 The roles of polyphenols in cancer chemoprevention. BioFactors 26 105-121. (doi:10.1002/biof.5520260202)

Lin HC, Chen YF, Hsu WH, Yang CW, Kao CH \& Tsai TF 2012 Resveratrol helps recovery from fatty liver and protects against hepatocellular carcinoma induced by hepatitis B virus X protein in a mouse model. Cancer Prevention Research 5 952-962. (doi:10.1158/1940-6207.CAPR12-0001)

Llovet JM, Burroughs A \& Bruix J 2003 Hepatocellular carcinoma. Lancet 362 1907-1917. (doi:10.1016/S0140-6736(03)14964-1)

Luther DJ, Ohanyan V, Shamhart PE, Hodnichak CM, Sisakian H, Booth TD, Meszaros JG \& Bishayee A 2011 Chemopreventive doses of resveratrol do not produce cardiotoxicity in a rodent model of hepatocellular carcinoma. Investigational New Drugs 29 380-391. (doi:10.1007/s10637009-9332-7)

Lyons MM, Yu C, Toma RB, Cho SY, Reiboldt W, Lee J \& van Breemen RB 2003 Resveratrol in raw and baked blueberries and bilberries. Journal of Agricultural and Food Chemistry 51 5867-5870. (doi:10.1021/jf034150f)

MacCarrone M, Lorenzon T, Guerrieri P \& Agro AF 1999 Resveratrol prevents apoptosis in K562 cells by inhibiting lipoxygenase and cyclooxygenase activity. European Journal of Biochemistry 265 27-34. (doi:10.1046/j.1432-1327.1999.00630.x)

Majumdar AP, Banerjee S, Nautiyal J, Patel BB, Patel V, Du J, Yu Y, Elliott AA , Levi E \& Sarkar FH 2009 Curcumin synergizes with resveratrol to inhibit colon cancer. Nutrition and Cancer 61 544-553. (doi:10.1080/ 01635580902752262)

Moller H, Mellemgaard A, Lindvig K \& Olsen JH 1994 Obesity and cancer risk: a Danish record-linkage study. European Journal of Cancer $\mathbf{3 0 A}$ 344-350. (doi:10.1016/0959-8049(94)90254-2)

Moon RT, Kohn AD, De Ferrari GV \& Kaykas A 2004 WNT and $\beta$-catenin signalling: diseases and therapies. Nature Reviews. Genetics 5 691-701. (doi:10.1038/nrg1427)

Murakami A, Matsumoto K, Koshimizu K \& Ohigashi H 2003 Effects of selected food factors with chemopreventive properties on combined lipopolysaccharide- and interferon- $\gamma$-induced I $\kappa$ B degradation in RAW264.7 macrophages. Cancer Letters 195 17-25. (doi:10.1016/ S0304-3835(03)00058-2)

Nakagawa H, Kiyozuka Y, Uemura Y, Senzaki H, Shikata N, Hioki K \& Tsubura A 2001 Resveratrol inhibits human breast cancer cell growth and may mitigate the effect of linoleic acid, a potent breast cancer cell stimulator. Journal of Cancer Research and Clinical Oncology 127 258-264. (doi:10.1007/s004320000190)

Newhauser WD \& Durante M 2011 Assessing the risk of second malignancies after modern radiotherapy. Nature Reviews. Cancer 11 438-448. (doi:10.1038/nrc3069)

Nguyen AV, Martinez M, Stamos MJ, Moyer MP, Planutis K, Hope C \& Holcombe RF 2009 Results of a phase I pilot clinical trial examining the effect of plant-derived resveratrol and grape powder on Wnt pathway target gene expression in colonic mucosa and colon cancer. Cancer Management and Research 1 25-37.

Oi N, Jeong CH, Nadas J, Cho YY, Pugliese A, Bode AM \& Dong Z 2010 Resveratrol, a red wine polyphenol, suppresses pancreatic cancer by inhibiting leukotriene A(4)hydrolase. Cancer Research 70 9755-9764. (doi:10.1158/0008-5472.CAN-10-2858)

Olsen GW, Mandel JS, Gibson RW, Wattenberg LW \& Schuman LM 1989 A case-control study of pancreatic cancer and cigarettes, alcohol, coffee and diet. American Journal of Public Health 79 1016-1019. (doi:10.2105/ AJPH.79.8.1016)

Patel KR, Brown VA, Jones DJ, Britton RG, Hemingway D, Miller AS, West KP, Booth TD, Perloff M, Crowell JA et al. 2010 Clinical pharmacology of resveratrol and its metabolites in colorectal cancer patients. Cancer Research 70 7392-7399. (doi:10.1158/0008-5472.CAN-10-2027)

Pearson KJ, Baur JA, Lewis KN, Peshkin L, Price NL, Labinskyy N, Swindell WR, Kamara D, Minor RK, Perez E et al. 2008 Resveratrol delays agerelated deterioration and mimics transcriptional aspects of dietary restriction without extending life span. Cell Metabolism 8 157-168. (doi:10.1016/j.cmet.2008.06.011)

Pervaiz S 2003 Resveratrol: from grapevines to mammalian biology. FASEB Journal 17 1975-1985. (doi:10.1096/fj.03-0168rev)

Popat R, Plesner T, Davies F, Cook G, Cook M, Elliott P, Jacobson E, Gumbleton T, Oakervee H \& Cavenagh J 2013 A phase 2 study of SRT501 (resveratrol) with bortezomib for patients with relapsed and or refractory multiple myeloma. British Journal of Haematology 160 714-717. (doi:10.1111/bjh.12154)

Poulsen MM, Vestergaard PF, Clasen BF, Radko Y, Christensen LP, Stodkilde-Jorgensen H, Moller N, Jessen N, Pedersen SB \& Jorgensen JO 2013 High-dose resveratrol supplementation in obese men: an investigator-initiated, randomized, placebo-controlled clinical trial of

Published by Bioscientifica Ltd 
substrate metabolism, insulin sensitivity, and body composition. Diabetes 62 1186-1195. (doi:10.2337/db12-0975)

Provinciali M, Re F, Donnini A, Orlando F, Bartozzi B, Di Stasio G \& Smorlesi A 2005 Effect of resveratrol on the development of spontaneous mammary tumors in HER-2/neu transgenic mice. International Journal of Cancer 115 36-45. (doi:10.1002/ijc.20874)

Rajasekaran D, Elavarasan J, Sivalingam M, Ganapathy E, Kumar A, Kalpana K \& Sakthisekaran D 2011 Resveratrol interferes with $\mathrm{N}$-nitrosodiethylamine-induced hepatocellular carcinoma at early and advanced stages in male Wistar rats. Molecular Medicine Reports 4 1211-1217.

Ramadori G, Gautron L, Fujikawa T, Vianna CR, Elmquist JK \& Coppari R 2009 Central administration of resveratrol improves diet-induced diabetes. Endocrinology 150 5326-5333. (doi:10.1210/en.2009-0528)

Reagan-Shaw S, Afaq F, Aziz MH \& Ahmad N 2004 Modulations of critical cell cycle regulatory events during chemoprevention of ultraviolet B-mediated responses by resveratrol in SKH-1 hairless mouse skin. Oncogene 23 5151-5160. (doi:10.1038/sj.onc.1207666)

Reagan-Shaw S, Nihal M \& Ahmad N 2008 Dose translation from animal to human studies revisited. FASEB Journal 22 659-661. (doi:10.1096/ fj.07-9574LSF)

Reen RK, Jamwal DS, Taneja SC, Koul JL, Dubey RK, Wiebel FJ \& Singh J 1993 Impairment of UDP-glucose dehydrogenase and glucuronidation activities in liver and small intestine of rat and guinea pig in vitro by piperine. Biochemical Pharmacology 46 229-238. (doi:10.1016/00062952(93)90408-O)

Renaud S \& de Lorgeril M 1992 Wine, alcohol, platelets, and the French paradox for coronary heart disease. Lancet 339 1523-1526. (doi:10.1016/0140-6736(92)91277-F)

Roy P, Madan E, Kalra N, Nigam N, George J, Ray RS, Hans RK, Prasad S \& Shukla Y 2009 Resveratrol enhances ultraviolet B-induced cell death through nuclear factor- $\kappa \mathrm{B}$ pathway in human epidermoid carcinoma A431 cells. Biochemical and Biophysical Research Communications 384 215-220. (doi:10.1016/j.bbrc.2009.04.100)

Roy SK, Chen Q, Fu J, Shankar S \& Srivastava RK 2011 Resveratrol inhibits growth of orthotopic pancreatic tumors through activation of FOXO transcription factors. PLOS ONE 6 e25166. (doi:10.1371/journal.pone. 0025166)

Salado C, Olaso E, Gallot N, Valcarcel M, Egilegor E, Mendoza L \& VidalVanaclocha F 2011 Resveratrol prevents inflammation-dependent hepatic melanoma metastasis by inhibiting the secretion and effects of interleukin-18. Journal of Translational Medicine 9 59. (doi:10.1186/ 1479-5876-9-59)

Sale S, Tunstall RG, Ruparelia KC, Potter GA, Steward WP \& Gescher AJ 2005 Comparison of the effects of the chemopreventive agent resveratrol and its synthetic analog trans 3,4,5, $4^{\prime}$-tetramethoxystilbene (DMU-212) on adenoma development in the Apc(Min+) mouse and cyclooxygenase-2 in human-derived colon cancer cells. International Journal of Cancer 115 194-201. (doi:10.1002/ijc. 20884)

Sancho E, Batlle E \& Clevers H 2004 Signaling pathways in intestinal development and cancer. Annual Review of Cell and Developmental Biology 20 695-723. (doi:10.1146/annurev.cellbio.20.010403.092805)

Sanders TH, McMichael RW Jr \& Hendrix KW 2000 Occurrence of resveratrol in edible peanuts. Journal of Agricultural and Food Chemistry 48 1243-1246. (doi:10.1021/jf990737b)

Sato M, Pei RJ, Yuri T, Danbara N, Nakane Y \& Tsubura A 2003 Prepubertal resveratrol exposure accelerates $N$-methyl- $N$-nitrosourea-induced mammary carcinoma in female Sprague-Dawley rats. Cancer Letters 202 137-145. (doi:10.1016/j.canlet.2003.08.016)

Schneider Y, Duranton B, Gosse F, Schleiffer R, Seiler N \& Raul F 2001 Resveratrol inhibits intestinal tumorigenesis and modulates hostdefense-related gene expression in an animal model of human familial adenomatous polyposis. Nutrition and Cancer 39 102-107. (doi:10.1207/S15327914nc391_14)

Seehusen DA, Baird D \& Bode D 2010 Primary care of adult survivors of childhood cancer. American Family Physician 81 1250-1255.
Seeni A, Takahashi S, Takeshita K, Tang M, Sugiura S, Sato SY \& Shirai T 2008 Suppression of prostate cancer growth by resveratrol in the transgenic rat for adenocarcinoma of prostate (TRAP) model. Asian Pacific Journal of Cancer Prevention 9 7-14.

Sengottuvelan M \& Nalini N 2006 Dietary supplementation of resveratrol suppresses colonic tumour incidence in 1,2-dimethylhydrazine-treated rats by modulating biotransforming enzymes and aberrant crypt foci development. British Journal of Nutrition 96 145-153. (doi:10.1079/ BJN20061789)

Sengottuvelan M, Deeptha K \& Nalini N 2009 Influence of dietary resveratrol on early and late molecular markers of 1,2-dimethylhydrazine-induced colon carcinogenesis. Nutrition 25 1169-1176. (doi:10.1016/j.nut.2009.03.009)

Shankar S, Nall D, Tang SN, Meeker D, Passarini J, Sharma J \& Srivastava RK 2011 Resveratrol inhibits pancreatic cancer stem cell characteristics in human and KrasG12D transgenic mice by inhibiting pluripotency maintaining factors and epithelial-mesenchymal transition. PLOS ONE 6 e16530. (doi:10.1371/journal.pone.0016530)

Shoba G, Joy D, Joseph T, Majeed M, Rajendran R \& Srinivas PS 1998 Influence of piperine on the pharmacokinetics of curcumin in animals and human volunteers. Planta Medica 64 353-356. (doi:10.1055/ s-2006-957450)

Shukla Y \& Singh R 2011 Resveratrol and cellular mechanisms of cancer prevention. Annals of the New York Academy of Sciences 1215 1-8. (doi:10.1111/j.1749-6632.2010.05870.x)

Siegel R, Naishadham D \& Jemal A 2012 Cancer statistics, 2012. CA: A Cancer Journal for Clinicians 62 10-29. (doi:10.3322/caac.20138)

Siegel R, Naishadham D \& Jemal A 2013 Cancer statistics, 2013. CA: A Cancer Journal for Clinicians 63 11-30. (doi:10.3322/caac.21166)

Silverman DT, Swanson CA, Gridley G, Wacholder S, Greenberg RS, Brown LM, Hayes RB, Swanson GM, Schoenberg JB, Pottern LM et al. 1998 Dietary and nutritional factors and pancreatic cancer: a case-control study based on direct interviews. Journal of the National Cancer Institute 90 1710-1719. (doi:10.1093/jnci/90.22.1710)

Singh CK, George J \& Ahmad N 2013 Resveratrol-based combinatorial strategies for cancer management. Annals of the New York Academy of Sciences 1290 113-121. (doi:10.1111/nyas.12160)

Soleas GJ, Angelini M, Grass L, Diamandis EP \& Goldberg DM 2001 Absorption of trans-resveratrol in rats. Methods in Enzymology 335 145-154.

Subbaramaiah K, Chung WJ, Michaluart P, Telang N, Tanabe T, Inoue H, Jang M, Pezzuto JM \& Dannenberg AJ 1998 Resveratrol inhibits cyclooxygenase-2 transcription and activity in phorbol ester-treated human mammary epithelial cells. Journal of Biological Chemistry 273 21875-21882. (doi:10.1074/jbc.273.34.21875)

Szekeres T, Saiko P, Fritzer-Szekeres M, Djavan B \& Jager W 2011 Chemopreventive effects of resveratrol and resveratrol derivatives. Annals of the New York Academy of Sciences 1215 89-95. (doi:10.1111/j. 1749-6632.2010.05864.x)

Tatlidede E, Sehirli O, Velioglu-Ogunc A, Cetinel S, Yegen BC, Yarat A, Suleymanoglu S \& Sener G 2009 Resveratrol treatment protects against doxorubicin-induced cardiotoxicity by alleviating oxidative damage. Free Radical Research 43 195-205. (doi:10.1080/10715760802673008)

Tessitore L, Davit A, Sarotto I \& Caderni G 2000 Resveratrol depresses the growth of colorectal aberrant crypt foci by affecting bax and p21(CIP) expression. Carcinogenesis 21 1619-1622. (doi:10.1093/carcin/21.8. 1619)

Timmers S, Konings E, Bilet L, Houtkooper RH, van de Weijer T, Goossens GH, Hoeks J, van der Krieken S, Ryu D, Kersten S et al. 2011 Calorie restriction-like effects of 30 days of resveratrol supplementation on energy metabolism and metabolic profile in obese humans. Cell Metabolism 14 612-622. (doi:10.1016/j.cmet.2011.10.002)

Tome-Carneiro J, Gonzalvez M, Larrosa M, Yanez-Gascon MJ, GarciaAlmagro FJ, Ruiz-Ros JA, Garcia-Conesa MT, Tomas-Barberan FA \& Espin JC 2012 One-year consumption of a grape nutraceutical containing resveratrol improves the inflammatory and fibrinolytic status of patients

Published by Bioscientifica Ltd. 
in primary prevention of cardiovascular disease. American Journal of Cardiology 110 356-363. (doi:10.1016/j.amjcard.2012.03.030)

Tome-Carneiro J, Larrosa M, Gonzalez-Sarrias A, Tomas-Barberan FA, Garcia-Conesa MT \& Espin JC 2013 Resveratrol and clinical trials: the crossroad from in vitro studies to human evidence. Current Pharmaceutical Design 19 6064-6093. (doi:10.2174/138161281131 99990407)

Trentham-Dietz A, Newcomb PA, Egan KM, Titus-Ernstoff L, Baron JA, Storer BE, Stampfer M \& Willett WC 2000 Weight change and risk of postmenopausal breast cancer (United States). Cancer Causes \& Control 11 533-542. (doi:10.1023/A:1008961931534)

Tsai SH, Lin-Shiau SY \& Lin JK 1999 Suppression of nitric oxide synthase and the down-regulation of the activation of NFKB in macrophages by resveratrol. British Journal of Pharmacology 126 673-680. (doi:10.1038/ sj.bjp.0702357)

Vainio H, Kaaks R \& Bianchini F 2002 Weight control and physical activity in cancer prevention: international evaluation of the evidence. European Journal of Cancer 11 (Suppl 2) S94-S100.

Vastano BC, Chen Y, Zhu N, Ho CT, Zhou Z \& Rosen RT 2000 Isolation and identification of stilbenes in two varieties of Polygonum cuspidatum. Journal of Agricultural and Food Chemistry 48 253-256. (doi:10.1021/ jf9909196)

Walle T, Hsieh F, DeLegge MH, Oatis JE Jr \& Walle UK 2004 High absorption but very low bioavailability of oral resveratrol in humans. Drug Metabolism and Disposition 32 1377-1382. (doi:10.1124/dmd.104. 000885)

Wang TT, Hudson TS, Wang TC, Remsberg CM, Davies NM, Takahashi Y, Kim YS, Seifried H, Vinyard BT, Perkins SN et al. 2008 Differential effects of resveratrol on androgen-responsive LNCaP human prostate cancer cells in vitro and in vivo. Carcinogenesis 29 2001-2010. (doi:10.1093/ carcin/bgn131)
Wechter WJ, Murray ED Jr, Kantoci D, Quiggle DD, Leipold DD, Gibson KM \& McCracken JD 2000 Treatment and survival study in the C57BL/6JAPC(Min)/+ (Min) mouse with R-flurbiprofen. Life Sciences 66 745-753. (doi:10.1016/S0024-3205(99)00645-1)

Wenzel E \& Somoza V 2005 Metabolism and bioavailability of trans-resveratrol. Molecular Nutrition \& Food Research 49 472-481. (doi:10.1002/mnfr.200500010)

Whitsett T, Carpenter M \& Lamartiniere CA 2006 Resveratrol, but not EGCG, in the diet suppresses DMBA-induced mammary cancer in rats. Journal of Carcinogenesis 5 15. (doi:10.1186/1477-3163-5-15)

Willett WC 1995 Diet, nutrition, and avoidable cancer. Environmental Health Perspectives 103 (Suppl 8) 165-170. (doi:10.1289/ehp. 95103s8165)

Wolk A 2005 Diet, lifestyle and risk of prostate cancer. Acta Oncologica 44 277-281. (doi:10.1080/02841860510029572)

Yang K, Popova NV, Yang WC, Lozonschi I, Tadesse S, Kent S, Bancroft L, Matise I, Cormier RT, Scherer SJ et al. 2008 Interaction of Muc2 and Apc on Wnt signaling and in intestinal tumorigenesis: potential role of chronic inflammation. Cancer Research 68 7313-7322. (doi:10.1158/ 0008-5472.CAN-08-0598)

Yoshino J, Conte C, Fontana L, Mittendorfer B, Imai S, Schechtman KB, Gu C, Kunz I, Rossi Fanelli F, Patterson BW et al. 2012 Resveratrol supplementation does not improve metabolic function in nonobese women with normal glucose tolerance. Cell Metabolism 16 658-664. (doi:10.1016/j.cmet.2012.09.015)

Yu C, Shin YG, Chow A, Li Y, Kosmeder JW, Lee YS, Hirschelman WH, Pezzuto JM, Mehta RG \& van Breemen RB 2002 Human, rat, and mouse metabolism of resveratrol. Pharmaceutical Research 19 1907-1914. (doi:10.1023/A:1021414129280)

Ziegler CC, Rainwater L, Whelan J \& McEntee MF 2004 Dietary resveratrol does not affect intestinal tumorigenesis in $\operatorname{Apc}(\operatorname{Min} /+)$ mice. Journal of Nutrition 134 5-10.

Received in final form 3 February 2014

Accepted 5 February 2014

Made available online as an Accepted Preprint

5 February 2014 http://erc.endocrinology-journals.org

DOI: 10.1530/ERC-13-0171
(C) 2014 The authors Printed in Great Britain
Published by Bioscientifica Ltd. 